\title{
Biomedical Applications of Silver Nanoparticles: An Up-to-Date Overview
}

\author{
Alexandra-Cristina Burdușel ${ }^{1}$, Oana Gherasim 2,3 , Alexandru Mihai Grumezescu ${ }^{2}$, \\ Laurențiu Mogoantă ${ }^{4}$, Anton Ficai ${ }^{2}$ and Ecaterina Andronescu ${ }^{2, *}$ \\ 1 Faculty of Engineering in Foreign Languages, University Politehnica of Bucharest, \\ 313 Splaiul Independenței, Bucharest 060042, Romania; alexandra_burdu@yahoo.com.sg \\ 2 Department of Science and Engineering of Oxide Materials and Nanomaterials, Faculty of Applied \\ Chemistry and Materials Science, University Politehnica of Bucharest, 1-7 Gheorghe Polizu Street, \\ Bucharest 011061, Romania; oana.fufa@gmail.com (O.G.); grumezescu@yahoo.com (A.M.G.); \\ anton.ficai@upb.ro (A.F.) \\ 3 Lasers Department, National Institute for Lasers, Plasma and Radiation Physics, 409 Atomiștilor Street, \\ Magurele 077125, Romania \\ 4 Research Center for Microscopic Morphology and Immunology, University of Medicine and Pharmacy of \\ Craiova, 2 Petru Rareș Street, Craiova 200349, Romania; laurentiu_mogoanta@yahoo.com \\ * Correspondence: ecaterina.andronescu@upb.ro; Tel.: +40-21-318-1000
}

Received: 1 August 2018; Accepted: 28 August 2018; Published: 31 August 2018

check for

Abstract: During the past few years, silver nanoparticles (AgNPs) became one of the most investigated and explored nanotechnology-derived nanostructures, given the fact that nanosilver-based materials proved to have interesting, challenging, and promising characteristics suitable for various biomedical applications. Among modern biomedical potential of AgNPs, tremendous interest is oriented toward the therapeutically enhanced personalized healthcare practice. AgNPs proved to have genuine features and impressive potential for the development of novel antimicrobial agents, drug-delivery formulations, detection and diagnosis platforms, biomaterial and medical device coatings, tissue restoration and regeneration materials, complex healthcare condition strategies, and performance-enhanced therapeutic alternatives. Given the impressive biomedical-related potential applications of AgNPs, impressive efforts were undertaken on understanding the intricate mechanisms of their biological interactions and possible toxic effects. Within this review, we focused on the latest data regarding the biomedical use of AgNP-based nanostructures, including aspects related to their potential toxicity, unique physiochemical properties, and biofunctional behaviors, discussing herein the intrinsic anti-inflammatory, antibacterial, antiviral, and antifungal activities of silver-based nanostructures.

Keywords: silver nanoparticles; biomedical applications; biological interactions; biofunctional performances; intrinsic anti-inflammatory activity; antimicrobial efficiency

\section{Introduction}

In the past few decades, tremendous interest and substantial research efforts were directed toward the biomedical evaluation and revaluation of metallic nanoparticles derived from noble metals, such as silver and gold, thanks to their specific and genuine chemical, biological, and physical properties $[1,2]$. In particular, impressive attention was oriented toward the biomedicine-related assessment of silver nanoparticles (AgNPs), which first attracted worldwide attention as unconventional antimicrobial agents [3-5]. Even though there is limited information regarding the toxicity and in vivo biological behavior of AgNPs, these nanostructures were used for a long time as antibacterial agents in the health industry [6,7], cosmetics [8,9], food storage [10,11], textile coatings [12,13], and some environmental 
applications [14-16]. AgNPs are a class of zero-dimensional materials with distinctive morphologies, having a size ranging from $1 \mathrm{~nm}$ to $100 \mathrm{~nm}$ [17].

As to the methods of obtaining AgNPs, different strategies were successfully used, thanks to the intrinsic versatility of silver metal and silver-based compounds, including physical [18,19], chemical [20,21], physicochemical [22,23], and biological synthesis approaches [24,25]. However, given the facile and safe process, reduced economic implications, and repeatability and reproducibility of experimental results, the method most used in the preparation of AgNPs is represented by the chemical reduction of silver salts by sodium citrate or sodium borohydrate [26,27]. In addition to their intrinsic antimicrobial-related applications, AgNPs were thoroughly explored thanks to their beneficial size-related physicochemical effects exhibited in novel electronic, magnetic, catalytic, and optical materials [28,29].

Special interest is oriented toward improving the stability of AgNPs, since a particular limitation of their antimicrobial-related use arises from their instability in bacteria-rich environments, and consequently, diminution or deprivation of their anti-pathogenic activity. In order to improve the stability of AgNPs in solution, many inorganic and organic [30,31], synthetic and natural [32,33], and biotic and abiotic materials were used as capping agents [34].

Though the precise anti-pathogenic mechanism of silver nanoparticles remains to be clarified, it is postulated that nanosilver-based systems exert their antimicrobial effects through the following phenomena: (a) microbial membrane damage, caused by the physicochemically guided attachment of AgNPs on the cell surface, and subsequent structural and functional alterations (such as gap formation, membrane destabilization, membrane piercing, and cytoplasm leakage); and (b) microbial sub-cellular structure damage, caused by the release of free $\mathrm{Ag}^{+}$ions and subsequent reactive oxygen species (ROS) generation or essential macromolecule (proteins, enzymes, and nucleotides) inactivation [35-37]. Still, the most remarkable mechanistic mode of AgNP-based antimicrobial effects is represented by their adhesion to microbial cells, ROS and free-radical generation, microbial wall piercing and penetration inside cells, and modulation and modification of microbial signal-transduction pathways [38]. Metallic silver ions are strong antimicrobials themselves, but they are easily isolated by phosphate and chloride functions, proteins, and different cellular components [39]. The intrinsic biocide or biostatic activity of AgNPs is strongly influenced by different physicochemical features, including morphology, size, oxidation and dissolution states, surface charge, and surface coating [37,40].

The effectiveness of nanosilver-based biomaterials as promising antimicrobial agents was experimentally assessed against a wide range of medically relevant planktonic and sessile pathogenic microorganisms, including bacteria [41,42], viruses [43,44], fungi, and yeasts $[45,46]$. The impressive antimicrobial activity of AgNPs is a solid starting point for the design, development, and implementation of new and performance-enhanced nanosilver-based biomedical products, such as anticancer agents, drug-delivery platforms, orthopedic materials and devices [47], bandages, antiseptic sprays, and catheters [48]. As a consequence of the impressive applicability of AgNPs in the fields of nanotechnology, biomedicine, and environment, there is a continuous need for the development of cost-effective methods for the synthesis of AgNPs [49]. The translation of silver-based nanotechnology to clinical applications requires not only the development of safe, simple, eco-friendly, and cost-effective methods for the synthesis of silver nanoparticles, but also a thorough understanding of the related physicochemical particularities, in vitro and in vivo effects, biodistribution, safety control mechanisms, pharmacokinetics, and pharmacodynamics of AgNPs [48].

\section{Antibacterial Characteristics of Silver Nanoparticles}

Silver nanoparticles attracted tremendous interest in the biomedical field, thanks to their attractive and unique nano-related properties, including their high intrinsic antimicrobial efficiency and non-toxic nature. Among the manifold potential applications of AgNPs in this particular domain, impressive attention and efforts were lately directed toward their promising implications in wound dressing, tissue scaffold, and protective clothing applications $[50,51]$. Some essential aspects related 
to the specific antimicrobial characteristics of AgNPs implies their intrinsic physical and chemical properties, which include maintaining the nanoscale size of AgNPs, improving their dispersion and stability, and avoiding aggregation [52]. There are many studies which experimentally proved that the anti-pathogenic activity of AgNPs is better than that exhibited by silver ions [53].

A major concern of the worldwide healthcare system is represented by the alarming and emerging phenomenon of pathogenic drug-resistant occurrence. Therefore, AgNPs represent potent candidates for the nanotechnology-derived development of novel and effective biocompatible nanostructured materials for unconventional antimicrobial applications [54]. Thanks to their intrinsic broad bactericidal effects exhibited against both Gram-negative and Gram-positive bacteria and their physicochemical properties, AgNPs are one of the most used metallic nanoparticles in modern antimicrobial applications [55]. Different studies reported that AgNPs interact with the bacterial membrane and penetrate the cell, thus producing a drastic disturbance regarding proper cell function, structural damage, and cell death [56]. We included in Figure 1 distinctive mechanisms described during the interaction of AgNPs with bacterial cells [57].

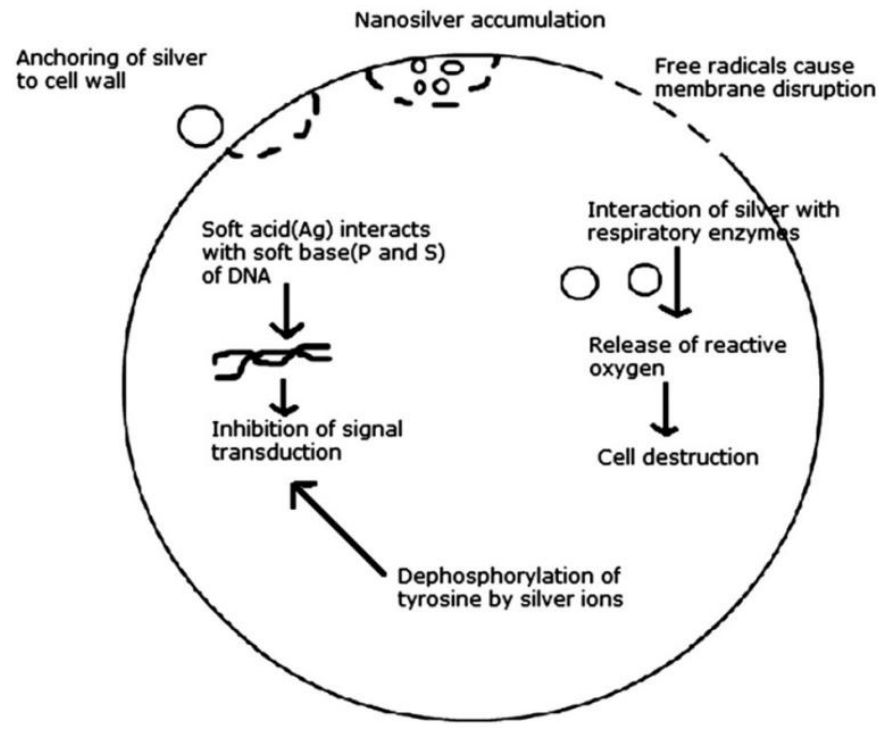

Figure 1. Various modes of action of silver nanoparticles (AgNPs) on bacteria [57].

Currently, it is shown that AgNPs can be successfully used to design and develop improved wound and burn dressings, thanks to the intrinsic antibacterial and anti-inflammatory effects of sole metallic nanoparticles [58]. Given the mutation-resistant antimicrobial activity related to nanosilver-based biomaterials, AgNPs are used in various pharmaceutical formulations as burn ointments, antibacterial clothing, and coatings for medical devices [59]. Different studies proved that the stabilization of AgNPs against dissolution and/or agglomeration can be achieved by using various capping agents, such as sodium citrate, polyvinylpyrrolidone (PVP), or polyethylene glycol (PEG) [60]. The stability of AgNPs was previously investigated, where the reported data indicated that their stability actively influences their toxicity [60].

The most important physicochemical parameters that affect the antimicrobial effects exhibited by AgNPs include size [61], shape [62], concentration [63], surface charge [64], and colloidal state [65]. As mentioned before, AgNPs display their intrinsic enhanced antimicrobial activity through various mechanisms [66].

It is also worth mentioning that the AgNP-based treatment of human cell cultures may induce cytotoxicity [67], inflammatory responses in a cell-type-dependent manner, and genotoxicity [66]. Thanks to their intrinsic capacity to provide stimuli-dependent responses through the specific modification of their optical properties, chemical environments, high molar absorptivity [68], and the 
many sorption sites found on their extensive surface [69], AgNPs are also used in various analytical applications. There are manifold research studies which particularly describe the biocide activity of silver itself [70].

The current state of the art relies on the beneficial conjunction between antimicrobial silver nanoparticles and natural or synthetic polymers, in the modern attempt to diminish or even eliminate the microbial contamination and colonization processes [71].

The major advantage of nanosilver-based biomaterials designed for unconventional antibacterial applications is related to their intrinsic anti-pathogenic effects exhibited against both planktonic and biofilm-organized microorganisms. The bactericidal activity of AgNPs is attributed to silver cations, which possess the ability to specifically bind to thiol groups of bacterial proteins, disrupting their physiological activity and leading to cell death. The effects of AgNPs on bacterial DNA were not analyzed in detail with respect to possible DNA lesions and antibacterial action that occur after AgNPs treatment. Silver nanoparticles exert their bactericidal activity through a Trojan-horse mechanism, since their initial binding to the cell surface leads to permeability alteration and cellular respiration impairment, followed by cell-barrier penetration and intracellular metallic silver ion release.

In order to successfully apply nanosilver-based systems as effective antibacterial agents, it is important to thoroughly understand their action against bacterial cells and bacterial biofilms [72]. In addition to their improved efficiency against planktonic bacteria (as discussed above), AgNPs also possess bactericide or bacteriostatic activity against biofilm-organized microorganisms. The antibacterial effects exhibited by silver-based nanosystems against biofilm-organized bacteria may be due to intrinsic activity against isolated or block cells, destabilization or disruption of the exopolymeric substances within the extracellular biofilm matrix, or interfering with bacterial signaling molecules [73-75]. There are ongoing discussions regarding the role of Ag ions released from AgNPs and their related toxic effect on microorganisms. Many researchers stated that the toxicity of AgNPs is due to the nanoparticles themselves, whereas others provided evidence that silver ions released from AgNPs play a crucial role during antimicrobial activity. Following the release of silver ions from AgNPs, antibacterial activity is initiated by metallic cations, rather than by metallic nanoparticles [76].

\section{Silver Nanoparticles for Drug-Delivery Systems}

In medicine, the pharmacokinetics and pharmacodynamics of drugs are as important as their intrinsic therapeutic effects [77]. Since the specific and selective delivery and action of therapeutic agents became one of the most studied topics for improving current human healthcare practice, nanoparticles received tremendous attention regarding the design and development of novel and enhanced drug-delivery systems [78]. In particular, AgNP-based nanosystems were evaluated as suitable carriers of various therapeutic molecules, including anti-inflammatory [79,80], anti-oxidant [81,82], antimicrobial [83,84], and anticancer [32,85] biosubstances.

In order to provide a specific therapeutic effect in human or animal organisms, it is essential to consider the process or method applied during the administration of the selected pharmaceutical compound [86]. For obtaining novel and performance-enhanced drug-delivery systems responsive to thermal, optical, or $\mathrm{pH}$ modulations to target inflammatory, infectious, and malignant ailments, hybrid molecular units consisting of AgNPs were successfully chosen, especially thanks to their exceptional biocompatibility and viable features for nanoscale-derived therapeutic settings [87].

As a consequence of the difficulty encountered during AgNP synthesis and the concerns regarding the toxicity and reduced stability of nanosilver-based systems when functionalized according to conventional salt-aging techniques, silver is not extensively used in nanoparticle-based drug-delivery applications, instead being replaced with gold or other nanomaterials [88]. An excellent triggerable and tunable nanosystem for drug-delivery applications should be easy to develop from readily available components, exhibit optimal responsiveness, and be compatible with more than one trigger [89]. Moreover, such a particular drug-delivery [90] platform should not only provide suitable and 
adjustable drug loading and releasing profiles, but should also enable [70] maximal therapeutic efficiency at concentrations below that of the sole biosubstance with side-effect minimization [91,92].

Thanks to their intrinsic anticancer activity [93], AgNPs attracted special attention for this particular domain, and were successfully evaluated as effective anti-tumor drug-delivery systems [94], acting either as passive $[95,96]$ or active $[97,98]$ nanocarriers for anticancer drugs. For the preparation of biocompatible AgNPs, different strategies were used, such as organic-water two-phase synthesis [99-101], micro-emulsion [102-104], radiolysis [105,106], and most commonly, reduction in aqueous solution $[94,107,108]$. Impressive attention, scientific knowledge, and financial support were lately oriented toward the formulation of AgNP-based drug-delivery platforms, thanks to the intrinsic features of nanosilver, including its capacity to bind a wide range of organic molecules, its tunable and strong absorption properties, and its low toxicity [109]. Recent studies evidenced the potential use of AgNPs as vaccine and drug carriers for specific and selective cell or tissue targeting [109]. In addition to the great optical properties of AgNPs (governed by specific surface plasmon resonance and localized surface plasmon resonance) [110-112], the recent improvements in AgNP biocompatibility and stability via surface modification strongly recommend nanostructured systems based on silver as specific, selective, and versatile candidates for drug-delivery applications [113].

\section{Silver Nanoparticles for Catheter Modification}

Central venous catheters (CVC) were firstly described by Niederhuber in 1982; since then, these devices became important therapeutic tools for diverse clinical conditions requiring malnutrition and replacement therapy (e.g., renal disease and cancer) [114]. CVCs are normally used to provide access for intravenous fluid administration, hemodynamics monitoring, drug-delivery pathways [115], and nutritional support in critically ill patients. Still, these medical devices are also a considerable source of hospital-acquired infections [116], and are considered a specific high-risk category of devices susceptible to microbial contamination and colonization phenomena [117]. A recent study showed that various Staphhylococcus aureus strains are responsible for catheter-related infections, and $82 \%$ of them are methicillin-resistant strains possessing many genes expressed in biofilm development and bacterial dispersion processes [118].

In order to induce antibacterial effects to clinically relevant materials and devices, AgNPs were extensively explored for the modification of one-dimensional and two-dimensional surfaces [119], such as cotton fabrics [120,121], natural and artificial fibers [122-124], thin polymer films [125,126], and wound pads $[127,128]$.

Even if silver (a half-noble metal) is susceptible to quick oxidation processes, the impressive surface-to-volume atomic ratio related to AgNPs accounts for the sustained local supply of $\mathrm{Ag}^{+}$ ions at the coating/tissue interface [129]. In recent studies, the role of AgNP-modified catheters as non-toxic devices capable of sustained release of bactericidal silver, exhibiting preventive effects against infection-related complications, was presented [116,130,131]. Given the fact that one of the major groups of organisms that causes device-related infections is represented by coagulase-negative staphylococci (CoNS), the effects exhibited by AgNPs and AgNP-coated catheters against these organisms were intimately studied [38]. Significant inhibitory effects against both Gram-positive and Gram-negative bacterial biofilm development were exhibited by CVCs coated with AgNPs [115,132-134].

Because the binding capacity of silver nanoparticles to bacterial cells is influenced by the surface area available for interaction, the bactericidal effects are expected to be size-dependent [135]. Catheters treated with silver ions represent a feasible strategy for reducing dialysis-related infections in patients undergoing peritoneal catheters; however, the antimicrobial efficiency and obtaining methods of $\mathrm{Ag}^{+}$are different [136]. Silver/copper-coated catheters were assessed as a promising solution for preventing methicillin-resistant Staphylococcus aureus (MRSA) infections, since their antibacterial activity might be improved by limiting non-specific plasma protein adsorption [137]. 
The main complication related to urinary catheterization is represented by the occurrence of catheter-associated urinary tract infections (CAUTIs) [138]. It was shown that a polymer matrix impregnated with AgNPs displayed hydrophilic surface properties, resulting in the prevention of bacterial biofilm formation and the deposition of proteins and electrolytes responsible for incrustation and adherence of microorganisms onto the surface [139]. With regards to silicon urethral catheters, Kocuran-capped silver glyconanoparticles were successfully evaluated as effective antibiofilm and antimicrobial coatings [118]. Despite the concerns regarding CVC-related complacency with respect to septic techniques, catheters with antimicrobial properties were taken into consideration as a feasible means of supplying additional protection against microbial contamination, further reducing colonization and infection risks [117].

\section{Silver Nanoparticles for Dental Applications}

Dental caries represent one of the most extensive oral-cavity-related affections worldwide, being also an economic burden [140]. By enhancing the remineralization process and controlling biofilm development, nanotechnology-derived dental-related strategies aim to limit or even eliminate the clinical impact of caries [140]. In addition to their intrinsic highly biocompatible behavior, the materials for dental barrier membranes (DBM), which are often used for efficient alveolar bone reconstruction, must accomplish some specific and additional features and functions [141]. Different metal-coated implants were evaluated against various pathogens responsible for dental-related biofilm formation and subsequent implant failure [142].

In order to prevent the pathogenic contamination of dental implants, proper tooth-brushing techniques, prophylactic antibiotics, and antimicrobial mouthwashes are specifically recommended [143]. A major goal in dentistry is to provide the proper protection of the oral cavity, which represents a pathogenic-susceptible gateway for the entire body [144]. Biofilms developed on dental implant surfaces may additionally cause inflammatory lesions on the peri-implant mucosa, thus increasing the risk of implant failure [145].

Silver was used for centuries in oral care and gained worldwide attention in the 19th century, being a major component in dental amalgams used for tooth restoration [146]. AgNPs were also used in various fields of dentistry, such as dental prostheses, restorative and endodontic dentistry, and implantology [147]. Thanks to their unique properties feasible for different domains of real interest in modern society, silver nanoparticles hold a prominent place in nanomaterial-related restorative, regenerative, and multifunctional biomedicine $[148,149]$.

An attractive strategy embraced by worldwide practitioners in order to provide additional bactericidal effects to general-use dental materials is to modify or embed them with silver-based nanostructures [150]. Though silver has favorable effects in caries prophylaxis in the form of nanosilver diamine fluoride (SDF), the use of this particular compound has some disadvantages, one of the most noticeable effects being represented by tooth staining [151]. By reducing the size of AgNPs, the contact surface will be considerably increased; in this way, the antimicrobial effects of silver would be improved, and the use of nanosilver could prevent black staining in teeth, which usually occurs after the application of SDF [152].

Antibacterial resins could be used in clinical dental applications, both in orthodontics and restorative dentistry [153]. In orthodontics, these resins could be used as bracket or branked bonding materials, while, in restorative dentistry, they could be used as filling or denture base material [153]. Therefore, in order to improve their physico-mechanical properties and antimicrobial effects, a method for incorporating AgNPs into acrylic resin denture-base materials was developed [154].

Because the oral cavity is an active ecosystem usually colonized by various pathogenic microorganisms, dental materials and implants have an increased risk of contamination and subsequent colonization processes [155]. In terms of superior antimicrobial activity, promising results were reported with respect to the incorporation of silver-based nanosystems within adhesive resins [156,157], orthodontic cements [158,159], and dental composites [160-162]. In addition to being used as 
antimicrobial filling agents within multifunctional biomaterials, another attractive and challenging dental application of AgNPs relies on their potential use as biostatic or biocide coatings for conventional titanium-based dental implants $[163,164]$. Though AgNPs proved to be efficient and effective agents in dental practice, they remain controversial candidates for this specific area of research, due to their variable toxicity in biological systems. Therefore, any potential application of AgNPs in dentistry must include thorough studies regarding the optimal compromise between physicochemical features and biofunctional performance [165].

\section{Silver Nanoparticles for Wound Healing}

Wound infections represent an important clinical challenge, with major impact on patient morbidity and mortality and notable economic implications [166]. Preventing wound dehiscence and surgical-site infection are challenging and essential aspects in current clinical practice [167]. The skin is the most extensive and one of the most complex organs in the human body, but it can be easily affected by different harmful external factors [168]. Physically or chemically induced cutaneous wounds may significantly disturb skin structural and functional integrity at different stages, leading to permanent disability or even death, depending on the severity of the injury [169]. In the past few years, wound infections caused by opportunistic pathogenic microorganism became an important issue during current healthcare practice [170]. The ultimate tendency and ideal desideratum for infected-wound management is represented by fast tissue-recovery processes, accompanied by maximal functionality restoration and minimal scar-tissue formation [171]. The wound-healing process, as any complex pathophysiological mechanism, includes different stages, such as coagulation, inflammation, cellular proliferation, and matrix and tissue remodeling [171].

Since ancient times, silver-based compounds and materials were used for the unconventional and effective control of distinctive infections [172]. Given its intrinsic physicochemical features and biological peculiarities, nanosilver provides a wide range of efficient biocide activities against an impressive diversity of anaerobic and aerobic, Gram-negative and Gram-positive bacterial strains. It is well known that bacterial and mammalian cells poorly absorb metallic or elemental silver, due to its chemical inactivation. Therefore, in order to provide specific antibacterial effects under physiological conditions (including the presence of body fluids or secretions), the ionization of silver is required. After their penetration inside cells, silver ions merge with enzymatic and structural proteins [173]. AgNPs or silver ions used in absorbent wound dressings can interact with and destroy the bacteria found in exudate [174].

Briefly, recent data provide the following information regarding AgNP skin absorption: (i) there is plenty experimental evidence with respect to the in vitro skin permeation by nanoparticles, and (ii) there is an important increase in permeation in the case of damaged skin [175]. When naturally available biopolymers (e.g., chitosan [176] or collagen [177]) are implied in novel nanotechnology approaches, they possess tremendous potential regarding the obtaining of novel and functionally improved platforms for effective wound-healing applications [178].

Acticoat $^{\mathrm{TM}}$ and Bactigras ${ }^{\mathrm{TM}}$ (Smith \& Nephew), Aquacel ${ }^{\mathrm{TM}}$ (ConvaTec), PolyMem Silver ${ }^{\mathrm{TM}}$ (Aspen), and Tegaderm ${ }^{\mathrm{TM}}(3 \mathrm{M})$ are representative biocomposites modified with ionic silver and approved by the United States (US) Food and Drug Administration (FDA) for wound-dressing applications. In addition to these commercial products, promising results were reported with respect to the incorporation of AgNPs within novel and naturally derived biomaterials for enhanced wound-healing management, such as (but not limited to) modified cotton fabrics [179,180], bacterial cellulose [181,182], chitosan [176,183], and sodium alginate [184,185].

The use of AgNPs and $\mathrm{Ag}^{+}$carriers also represents a valuable strategy for delayed diabetic wound-healing processes, since diabetic wounds may be accompanied by numerous secondary infections. AgNPs can help diabetic patients in early wound-healing stages, additionally providing minor scars [186]. Taking into account the efficient and enhanced antibacterial effects exhibited 
by AgNPs and the impressive interest oriented toward their application in wound therapy and medical-device coatings, their biocompatibility and safety aspects must be thoroughly clarified [187].

\section{Silver Nanoparticles for Bone Healing}

Every year, millions of people worldwide are affected by distinctive and complex bone-related pathologies, including infectious diseases, degenerative and genetic conditions, cancers, and fractures [188]. Unfortunately, the opportunistic contamination and colonization of orthopedic implants represent major concerns in osseous-tissue replacement strategies, since the related infections are associated with high morbidity [189]. Bone is an active tissue that undergoes regenerative and restorative processes through the intrinsic and complex bone-remodeling mechanism [190]. Bone grafts are usually implanted to replace or restore severe defects that irremediably affect osseous tissue, such as genetic malformations, tumors, or traumas [191]. Orthopedic and bone-implant-related infections are usually associated with highly inflammatory processes and subsequent implant loss and bone-destruction phenomena [192].

Previous studies reported that AgNPs naturally improve the differentiation process of MC3T3-1 pre-osteoblast cells and subsequent bone-like tissue mineralization, when compared with other NPs [193]. Currently, silver-coated prostheses represent an unconventional approach during the prophylaxis of tumor-related infections and extensive trauma-related infections. However, no clinical studies comparing the long-term clinical impact of nanosilver-coated implants for revision arthroplasty are reported as of yet [194]. The self-repairing capability of bone can be limited when bacterial activity occurs in bone defects. Compared with usual antibiotics, AgNPs possess intrinsic antibacterial activity with a broader spectrum. Also, the bacterial resistance to AgNP activity is an uncommon phenomenon, thus emphasizing that the bactericidal mechanisms of nanosilver act in synergy. Thanks to this peculiar property, AgNPs have the capability to inhibit or impair biofilm development or mature biofilm, respectively, in the case of antibiotic-resistant bacteria, such as methicillin-resistant Staphylococcus aureus [195].

Human bone, dentin, and dental enamel are mainly composed of crystallized hydroxyapatite (HA), which is a calcium-phosphate salt [196]. Given the specific biocompatibility of biosynthesized and synthetic HA, this material and its derivatives are extensively explored for the development of unconventional osseous-related restorative and regenerative strategies, either as artificial bone grafts or as coating materials for metallic implants [197]. With regards to the superficial modification of various metallic implant surfaces, biocompatible HA integrated with silver (either in metallic or ionic form) represents a suitable choice for the fabrication of bioactive and antimicrobial bone implants [198]. The antimicrobial efficiency of HA-based coatings embedded with nanosilver was evidenced against Gram-positive [199-201] and Gram-negative [202-204] bacterial strains.

In terms of bone-replacement procedures, AgNPs are normally used as doping materials for synthetic and bio-inspired bone scaffolds, with relevant results being recently reported [205,206]. In order to induce antibacterial properties in HA coatings, several experimental techniques proved suitable for the incorporation of nanosilver within calcium-phosphate materials, such as laser-assisted deposition, electrochemical deposition, magnetron sputtering, ion-beam-assisted deposition, sol-gel technology, and microarc oxidation [207].

Previous studies showed that AgNP-implanted titanium displayed improved antibacterial ability, as well as excellent compatibility with osteoblasts, thanks to the micro-galvanic effects produced between the implanted AgNPs and the titanium substrate [208]. Many studies investigated the feasibility and clinical potential of adjusting acrylic cements with AgNPs, in order to provide unconventional and functionally improved biomaterials for orthopedic applications. While previous studies explored different acrylics modified with AgNPs, a significant part of the previous work is limited, since vital material characteristics and mechanical properties were not thoroughly analyzed [159,209-211]. 
Moreover, the beneficial addition of antimicrobial AgNPs within composite matrices designed for bone-tissue engineering were emphasized. In a recent study, it was shown that AgNPs could promote the osteogenesis and proliferation of mesenchymal stem cells (MSCs), in order to enhance the healing process of bone fracture [212]. A correlation was also reported between NP uptake and growth in clathrin-dependent endocytosis in the case of MSCs and osteoblasts, indicating that this route may represent the principal cellular internalization pathway of AgNPs [213]. Taking into account the limited capacity of bone tissue to fully reconstruct or replace severe defects, the development of novel and performance-enhanced implants is required. Thus, new pathways were used to stimulate bone regeneration and also to prevent the side effects correlated with therapeutics currently used in the clinic [214].

\section{Silver Nanoparticles for Other Medical Applications}

Thanks to their unique physiochemical properties and biofunctional features, such as anti-inflammatory, anti-angiogenesis, antiplatelet, antiviral, antifungal, and antibacterial activities, AgNPs play an important role in the development and implementation of novel biomedicinal strategies [45]. Recently, AgNPs were intimately investigated regarding their promising anticancer effects exhibited in different human cancerous cell lines, such as endothelial cells, IMR-90 lung fibroblasts, U251 glioblastoma cells, and MDA-MB-231 breast cancer cells [215,216]. AgNPs possess the intrinsic capability to merge with mammalian cells and to easily penetrate them by means of energy-driven internalization pathways [217]. Another attractive property of AgNPs relies on their specific fluorescence, making them suitable candidates for detection and dose-enhancement purposes in X-ray irradiation applications [218].

At the moment, the combination of therapy and diagnosis, known as theranostics, represents the most important, attractive, and challenging approach embraced by healthcare practitioners and researchers with respect to the effective and personalized therapy of cancer desideratum [219]. AgNPs are also plasmonic structures, capable of particularly scattering and absorbing the light impinging certain areas. After their selective uptake into cancerous cells, AgNP-derived scattered light can be used for imaging purposes, whereas absorbed light can be used for selective hyperthermia [220].

Cardiovascular diseases (CVDs) represent a major cause of worldwide human death, being responsible for more than 17.7 million deaths in 2015 [221]. Recently, many studies focused on the evaluation of the effects of AgNPs on various types of cell encountered in the complex vascular system, but the reported results were contradictory. However, the collected data can provide substantial knowledge with respect to the potential benefits of AgNPs for pathological and physiological stages related to the cardiovascular system, thus contributing to the development of novel and specific molecular therapies in vascular tone, vasopermeability, and angiogenesis [222]. Cardiovascular pathologies, such as hypertension, may influence the toxic effects induced by AgNPs [223]. The first silver-modified cardiovascular medical device was a prosthetic silicone heart valve coated with elemental silver, which was developed to avoid valve-related bacterial infection and to reduce inflammation response [224].

Malaria, one of the most common infectious diseases encountered in tropical and sub-tropical regions, became a major healthcare concern all around the world. It was shown that AgNPs possess powerful activity against both the malarial parasite (Plasmodium falciparum) and its related vector (Anopheles female mosquito). The intrinsic anti-plasmodial effects exhibited by nanosilver-based compounds and materials represent a solid starting point toward the nanotechnology-derived therapy and worldwide control of malaria [24,225,226].

The human eye is a complex organ, with impressive vascularization and innervation, that can be easily exposed to microbial contamination under proper temperature and humidity conditions $[227,228]$. Nanosilver-based compounds and materials proved promising potential toward the development of unconventional and performance-enhanced therapy of eye-related infectious conditions. AgNPs coated with calcium indicators proved to have reduced damage with respect to 
retinal cells, and could be experimentally applied for retinal imaging in a mouse animal model [229,230]. The bactericidal effects related to AgNP-containing nanomaterials are essential aspects which must be further considered for their exploitation as an improved class of antibacterial agent for ocular applications [14,231,232].

AgNPs can be successfully used as novel nanostructured platforms for diagnostics and the treatment of different cancers [233]. The broad-spectrum bioactivity of AgNPs makes them promising agents not only for anti-infective fighting strategies, but also in critical tumor and multi-drug resistance tackling approaches.

\section{Toxicity of Silver Nanoparticles}

Even if AgNPs possess tremendous advantages that recommend them for novel and challenging biomedical applications, their toxicity became an intensive study subject only recently. The daily amount of silver derived from natural sources in food and water ingested by humans is approximately 0.4-30 $\mu \mathrm{g}$ [234]. The available studies performed with respect to the toxic effects exhibited by AgNPs within biological systems, such as bacteria and viruses or human cells, report contradictory and various results $[235,236]$. AgNPs are generally presented as highly effective antimicrobial agents with non-toxic effects to healthy mammalian cells [237]. However, various in vitro studies demonstrated the nanosilver-related toxic effects in rat hepatocytes and neuronal cells [238], murine stem cells, and human lung epithelial cells [239]. The toxicity of AgNPs was also investigated during in vivo assays. The toxicity studies performed in a rat ear model proved that AgNP exposure resulted in significant mitochondrial dysfunction and subsequent temporary or permanent hearing loss, depending on the inoculation dose. Even low concentrations of AgNPs were absorbed by retinal cells and resulted in important structural disruption, due to the increased number of cells that underwent oxidative stress [240].

The possible toxicity mechanisms related to AgNPs are depicted in Figure 2 [241]. The performed studies also proved that variations in surface charge resulting from the surface functionalization of AgNPs can impact cellular uptake, translocation to various tissues, and cytotoxicity. The magnitude of the surface charge, as measured by the zeta potential, can influence the amount of nanoparticles and their mechanism of uptake into cells [242].

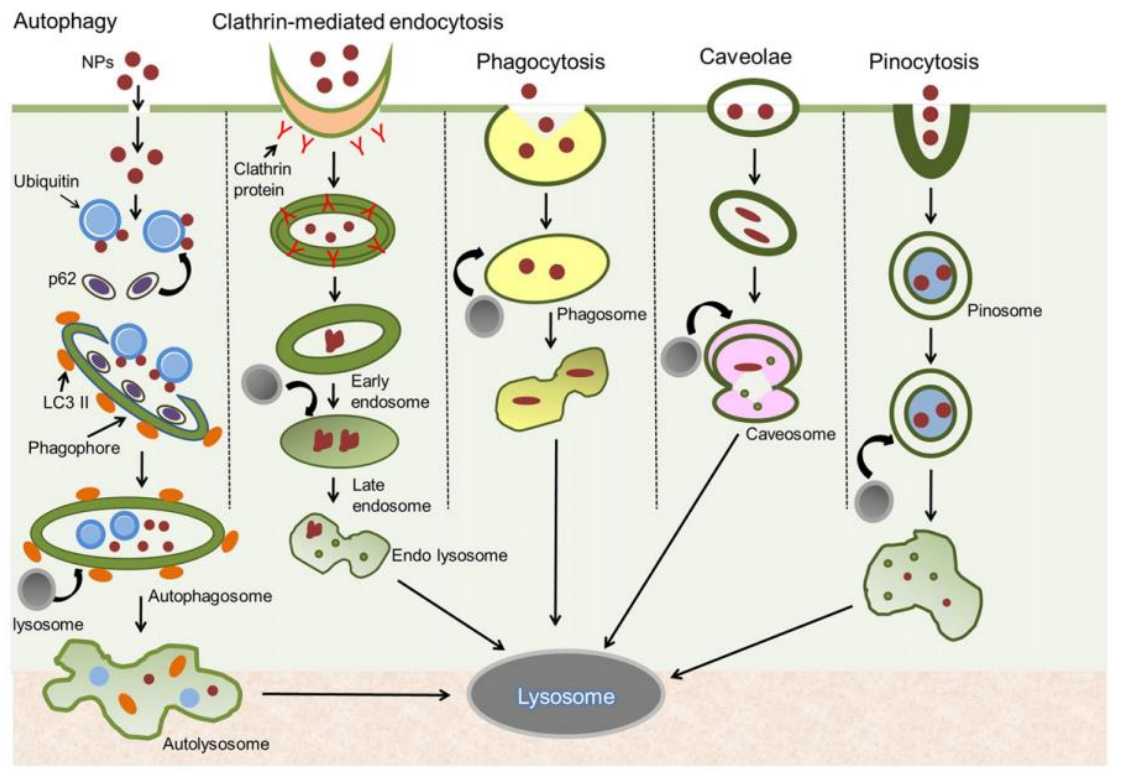

Figure 2. Schematic representation of plausible methods of cellular uptake of AgNPs [243]. Reprinted with permission from [243]. Elsevier, 2015. 
In order to investigate the toxic effects caused by exposure to nanosilver-based systems, thorough assays are required, considering both cellular and animal models. Regarding the in vivo biocompatibility and biodistribution assays, the reported data evidenced that AgNPs can result in structural and physiological alteration of vital organs. For example, inhaled AgNPs may form deposits in the alveolar regions, leading to lung injuries, and may also generate significant modifications within the nervous system, and liver and kidney tissues. Intratracheal instillation of AgNPs can affect vascular reactivity and can further exacerbate cardiac reperfusion/ischemia injury [244,245].

The toxicity of AgNPs is related to their transformation under biological conditions and environmental media, including their interactions with biological macromolecules, surface oxidation, and the release of silver ions. Also, it is very important to precisely distinguish the toxicity rate related to either nanosized silver or ionic silver [246]. Many studies proved that AgNP exposure can induce a decrease in cell viability through different cellular mechanisms. One of these mechanisms is represented by the induction of apoptosis-related genes and the activation of apoptosis mechanism. Also, it was proven that nanosilver can cause the formation and intracellular accumulation of ROS, modification of mitochondrial membrane permeability, and DNA damage [247-249]. The in vitro toxicity of AgNPs was investigated in several research studies, but there is still a lack of consistent and reliable data. This is a general concern in nanotoxicology, and more research coherence is needed to produce meaningful results. According to recent data, the main in vitro outcomes occurring upon exposure to AgNPs were reported as increases in oxidative stress, genotoxicity, and apoptosis levels [250-252]. AgNPs may induce significant oxidative damage with respect to the cellular membrane and organelles such as the nucleus, mitochondria, and lysosomes, thus leading directly to necrotic or apoptotic phenomena. The oxidative stress caused by AgNPs can result in inflammatory responses, including the activation of innate immunity and increasing the permeability of endothelial cells [253]. AgNPs, inoculated at non-cytotoxic doses, may cause chromosomal abnormality, DNA damage, and possible mutagenicity [254-256].

The genotoxicity and cytotoxicity of AgNPs are influenced by several physicochemical features, including dispersion rate, concentration, surface charge, size, morphology, and surface functionalization $[257,258]$. The physicochemical aspects of nanosilver-based systems and materials mainly distribute and categorize numerous toxicological concerns, and also establish a ladder of toxicity framework while imposing on the biological system. The experimental results reported until recently are insufficient regarding the accurate toxic effects of AgNPs and their related toxicity mechanisms $[35,259]$.

\section{Conclusions}

Silver nanoparticles (AgNPs) are intensively explored nanostructures for unconventional and enhanced biomedical applications, thanks to their size-related attractive physicochemical properties and biological functionality, including their high antimicrobial efficiency and non-toxic nature. AgNP-based nanosystems and nanomaterials are suitable alternatives for drug delivery, wound dressing, tissue scaffold, and protective coating applications. Various physicochemical parameters were related to the intrinsic antimicrobial effects exhibited by AgNPs, such as size, shape, concentration, surface charge, and colloidal state. Moreover, the impressive available surface of nanosilver allows the coordination of many ligands, thus enabling tremendous possibilities with respect to the surface functionalization of AgNPs.

There is a significant amount of research data proving the beneficial effects of AgNPs in novel biocompatible and nanostructured materials and devices developed for modern therapeutic strategies. In addition to their attractive and versatile antimicrobial potential, AgNPs provide additional mechanical, optical, chemical, and biological peculiarities that recommend them for the design, obtaining, evaluation, and clinical assessment of performance-enhanced biomaterials and medical devices. Still, thorough investigations regarding their short-term and long-term toxicity, as well as the responsible toxic-related mechanisms, are required. 
The current limitations related to conventional healthcare practice and the latest challenges resulting from nanosilver-based technology outline the impressive potential of silver nanoparticles in biomedicinal applications. Whether we consider the modification of available biomaterials and devices or the development of novel nanostructured ones, AgNPs are ideal candidates for achieving the very close modern biomedicine desideratum.

Author Contributions: A.-C.B., O.G., A.M.G., L.M., A.F., and E.A. designed and wrote the paper.

Acknowledgments: This work was supported by a grant from the Romanian National Authority for Scientific Research and Innovation, UEFISCDI, project number 45PCCDI/2018-Nanostructuri bioactive pentru strategii terapeutice inovatoare.

Conflicts of Interest: The authors declare no conflict of interest.

\section{References}

1. Abou El-Nour, K.M.M.; Eftaiha, A.; Al-Warthan, A.; Ammar, R.A.A. Synthesis and applications of silver nanoparticles. Arab. J. Chem. 2010, 3, 135-140. [CrossRef]

2. Faisal, N.; Kumar, K. Polymer and metal nanocomposites in biomedical applications. Biointerface Res. Appl. Chem. 2017, 7, 2286-2294.

3. Alexander, J.W. History of the medical use of silver. Surg. Infect. 2009, 10, 289-292. [CrossRef] [PubMed]

4. Ioan-Avram, N.; Anton, F.; Maria, S.; Denisa, F.; Ovidiu, O.; Ecaterina, A. Silver based materials for biomedical applications. Curr. Org. Chem. 2014, 18, 173-184.

5. Geraldo, D.A.; Needham, P.; Chandia, N.; Arratia-Perez, R.; Mora, G.C.; Villagra, N.A. Green synthesis of polysaccharides-based gold and silver nanoparticles and their promissory biological activity. Biointerface Res. Appl. Chem. 2016, 6, 1263-1271.

6. Chowdhury, N.R.; MacGregor-Ramiasa, M.; Zilm, P.; Majewski, P.; Vasilev, K. 'Chocolate' silver nanoparticles: Synthesis, antibacterial activity and cytotoxicity. J. Colloid Interface Sci. 2016, 482, 151-158. [CrossRef] [PubMed]

7. Tavaf, Z.; Tabatabaei, M.; Khalafi-Nezhad, A.; Panahi, F. Evaluation of antibacterial, antibofilm and antioxidant activities of synthesized silver nanoparticles (AgNPs) and casein peptide fragments against streptococcus mutans. Eur. J. Integr. Med. 2017, 12, 163-171. [CrossRef]

8. Domeradzka-Gajda, K.; Nocun, M.; Roszak, J.; Janasik, B.; Quarles, C.D., Jr.; Wasowicz, W.; Grobelny, J.; Tomaszewska, E.; Celichowski, G.; Ranoszek-Soliwoda, K.; et al. A study on the in vitro percutaneous absorption of silver nanoparticles in combination with aluminum chloride, methyl paraben or di-n-butyl phthalate. Toxicol. Lett. 2017, 272, 38-48. [CrossRef] [PubMed]

9. Kraeling, M.E.K.; Topping, V.D.; Keltner, Z.M.; Belgrave, K.R.; Bailey, K.D.; Gao, X.; Yourick, J.J. In vitro percutaneous penetration of silver nanoparticles in pig and human skin. Regul. Toxicol. Pharm. 2018, 95, 314-322. [CrossRef] [PubMed]

10. Fortunati, E.; Peltzer, M.; Armentano, I.; Jiménez, A.; Kenny, J.M. Combined effects of cellulose nanocrystals and silver nanoparticles on the barrier and migration properties of pla nano-biocomposites. J. Food Eng. 2013, 118, 117-124. [CrossRef]

11. Kumar, S.; Shukla, A.; Baul, P.P.; Mitra, A.; Halder, D. Biodegradable hybrid nanocomposites of chitosan/gelatin and silver nanoparticles for active food packaging applications. Food Packag. Shelf 2018, 16, 178-184. [CrossRef]

12. Pannerselvam, B.; Dharmalingam Jothinathan, M.K.; Rajenderan, M.; Perumal, P.; Pudupalayam Thangavelu, K.; Kim, H.J.; Singh, V.; Rangarajulu, S.K. An in vitro study on the burn wound healing activity of cotton fabrics incorporated with phytosynthesized silver nanoparticles in male Wistar albino rats. Eur. J. Pharm. Sci. 2017, 100, 187-196. [CrossRef] [PubMed]

13. Zhou, Y.; Tang, R.C. Facile and eco-friendly fabrication of agnps coated silk for antibacterial and antioxidant textiles using honeysuckle extract. J. Photochem. Photobiol. B 2018, 178, 463-471. [CrossRef] [PubMed]

14. Kejlová, K.; Kašpárková, V.; Krsek, D.; Jírová, D.; Kolářová, H.; Dvořáková, M.; Tománková, K.; Mikulcová, V. Characteristics of silver nanoparticles in vehicles for biological applications. Int. J. Pharm. 2015, 496, 878-885. [CrossRef] [PubMed] 
15. Zhang, L.; Zeng, G.; Dong, H.; Chen, Y.; Zhang, J.; Yan, M.; Zhu, Y.; Yuan, Y.; Xie, Y.; Huang, Z. The impact of silver nanoparticles on the co-composting of sewage sludge and agricultural waste: Evolutions of organic matter and nitrogen. Bioresour. Technol. 2017, 230, 132-139. [CrossRef] [PubMed]

16. Gupta, S.D.; Agarwal, A.; Pradhan, S. Phytostimulatory effect of silver nanoparticles (AgNPs) on rice seedling growth: An insight from antioxidative enzyme activities and gene expression patterns. Ecotoxicol. Environ. Saf. 2018, 161, 624-633. [CrossRef] [PubMed]

17. Achmad, S.; Salmiati; Razman, S.M.; Ahmad, B.H.K.; Tony, H.; Hadi, N. A review of silver nanoparticles: Research trends, global consumption, synthesis, properties, and future challenges. J. Chin. Chem. Soc. 2017, 64, 732-756.

18. Brobbey, K.J.; Haapanen, J.; Gunell, M.; Mäkelä, J.M.; Eerola, E.; Toivakka, M.; Saarinen, J.J. One-step flame synthesis of silver nanoparticles for roll-to-roll production of antibacterial paper. Appl. Surf. Sci. 2017, 420, 558-565. [CrossRef]

19. He, R.; Ren, F.; Chen, F. Embedded silver nanoparticles in ktp crystal produced by ion implantation. Mater. Lett. 2017, 193, 158-160. [CrossRef]

20. Han, H.J.; Yu, T.; Kim, W.-S.; Im, S.H. Highly reproducible polyol synthesis for silver nanocubes. J. Cryst. Growth 2017, 469, 48-53. [CrossRef]

21. Khatoon, U.T.; Nageswara Rao, G.V.S.; Mohan, K.M.; Ramanaviciene, A.; Ramanavicius, A. Antibacterial and antifungal activity of silver nanospheres synthesized by tri-sodium citrate assisted chemical approach. Vacuum 2017, 146, 259-265. [CrossRef]

22. Verma, S.; Rao, B.T.; Srivastava, A.P.; Srivastava, D.; Kaul, R.; Singh, B. A facile synthesis of broad plasmon wavelength tunable silver nanoparticles in citrate aqueous solutions by laser ablation and light irradiation. Colloids Surf. A Physicochem. Eng. Asp. 2017, 527, 23-33. [CrossRef]

23. Liu, F.; Liu, J.; Cao, X. Microwave-assisted synthesis silver nanoparticles and their surface enhancement raman scattering. Rare Met. Mater. Eng. 2017, 46, 2395-2398.

24. Dutta, P.P.; Bordoloi, M.; Gogoi, K.; Roy, S.; Narzary, B.; Bhattacharyya, D.R.; Mohapatra, P.K.; Mazumder, B. Antimalarial silver and gold nanoparticles: Green synthesis, characterization and in vitro study. Biomed. Pharmacother. 2017, 91, 567-580. [CrossRef] [PubMed]

25. Singh, T.; Jyoti, K.; Patnaik, A.; Singh, A.; Chauhan, R.; Chandel, S.S. Biosynthesis, characterization and antibacterial activity of silver nanoparticles using an endophytic fungal supernatant of raphanus sativus. J. Genet. Eng. Biotechnol. 2017, 15, 31-39. [CrossRef]

26. Mahmoud, K.H.; Abbo, M. Synthesis, characterization and optical properties of gelatin doped with silver nanoparticles. Spectrochim. Acta Part A Mol. Biomol. Spectrosc. 2013, 116, 610-615. [CrossRef] [PubMed]

27. Hanif, M.; Juluri, R.R.; Fojan, P.; Popok, V.N. Polymer films with size-selected silver nanoparticles as plasmon resonance-based transducers for protein sensing. Biointerface Res. Appl. Chem. 2016, 6, 1564-1568.

28. Higa, A.M.; Mambrini, G.P.; Hausen, M.; Strixino, F.T.; Leite, F.L. Ag-nanoparticle-based nano-immunosensor for anti-glutathione s-transferase detection. Biointerface Res. Appl. Chem. 2016, 6, 1053-1058.

29. Qiu, C.; Bennet, K.E.; Tomshine, J.R.; Hara, S.; Ciubuc, J.D.; Schmidt, U.; Durrer, W.G.; McIntosh, M.B.; Eastman, M.; Manciu, F.S. Ultrasensitive detection of neurotransmitters by surface enhanced raman spectroscopy for biosensing applications. Biointerface Res. Appl. Chem. 2017, 7, 1921-1926.

30. Chien, C.-S.; Lin, C.-J.; Ko, C.-J.; Tseng, S.-P.; Shih, C.-J. Antibacterial activity of silver nanoparticles (AgNP) confined to mesostructured silica against methicillin-resistant staphylococcus aureus (MRSA). J. Alloys Compd. 2018, 747, 1-7. [CrossRef]

31. Lau, C.P.; Abdul-Wahab, M.F.; Jaafar, J.; Chan, G.F.; Abdul Rashid, N.A. Toxic effect of high concentration of sonochemically synthesized polyvinylpyrrolidone-coated silver nanoparticles on citrobacter sp. A1 and enterococcus sp. C1. J. Microbiol. Immunol. Infect. 2017, 50, 427-434. [CrossRef] [PubMed]

32. Muhammad, Z.; Raza, A.; Ghafoor, S.; Naeem, A.; Naz, S.S.; Riaz, S.; Ahmed, W.; Rana, N.F. Peg capped methotrexate silver nanoparticles for efficient anticancer activity and biocompatibility. Eur. J. Pharm. Sci. 2016, 91, 251-255. [CrossRef] [PubMed]

33. Panzarini, E.; Mariano, S.; Vergallo, C.; Carata, E.; Fimia, G.M.; Mura, F.; Rossi, M.; Vergaro, V.; Ciccarella, G.; Corazzari, M.; et al. Glucose capped silver nanoparticles induce cell cycle arrest in hela cells. Toxicol. In Vitro 2017, 41, 64-74. [CrossRef] [PubMed] 
34. He, H.; Tao, G.; Wang, Y.; Cai, R.; Guo, P.; Chen, L.; Zuo, H.; Zhao, P.; Xia, Q. In situ green synthesis and characterization of sericin-silver nanoparticle composite with effective antibacterial activity and good biocompatibility. Mater. Sci. Eng. C 2017, 80, 509-516. [CrossRef] [PubMed]

35. Akter, M.; Sikder, M.T.; Rahman, M.M.; Ullah, A.K.M.A.; Hossain, K.F.B.; Banik, S.; Hosokawa, T.; Saito, T.; Kurasaki, M. A systematic review on silver nanoparticles-induced cytotoxicity: Physicochemical properties and perspectives. J. Adv. Res. 2018, 9, 1-16. [CrossRef] [PubMed]

36. Zheng, K.; Setyawati, M.I.; Leong, D.T.; Xie, J. Antimicrobial silver nanomaterials. Coord. Chem. Rev. 2018, 357, 1-17. [CrossRef]

37. Durán, N.; Durán, M.; de Jesus, M.B.; Seabra, A.B.; Fávaro, W.J.; Nakazato, G. Silver nanoparticles: A new view on mechanistic aspects on antimicrobial activity. Nanomed. Nanotechnol. Biol. Med. 2016, 12, 789-799. [CrossRef] [PubMed]

38. Thomas, R.; Soumya, K.R.; Mathew, J.; Radhakrishnan, E.K. Inhibitory effect of silver nanoparticle fabricated urinary catheter on colonization efficiency of coagulase negative staphylococci. J. Photochem. Photobiol. B Biol. 2015, 149, 68-77. [CrossRef] [PubMed]

39. Marassi, V.; Di Cristo, L.; Smith, S.G.J.; Ortelli, S.; Blosi, M.; Costa, A.L.; Reschiglian, P.; Volkov, Y.; Prina-Mello, A. Silver nanoparticles as a medical device in healthcare settings: A five-step approach for candidate screening of coating agents. R. Soc. Open Sci. 2018, 5, 171113. [CrossRef] [PubMed]

40. Koduru, J.R.; Kailasa, S.K.; Bhamore, J.R.; Kim, K.-H.; Dutta, T.; Vellingiri, K. Phytochemical-assisted synthetic approaches for silver nanoparticles antimicrobial applications: A review. Adv. Colloid Interface Sci. 2018, 256, 326-339. [CrossRef] [PubMed]

41. Alshareef, A.; Laird, K.; Cross, R.B.M. Shape-dependent antibacterial activity of silver nanoparticles on Escherichia coli and Enterococcus faecium bacterium. Appl. Surf. Sci. 2017, 424, 310-315. [CrossRef]

42. Adur, A.J.; Nandini, N.; Shilpashree Mayachar, K.; Ramya, R.; Srinatha, N. Bio-synthesis and antimicrobial activity of silver nanoparticles using anaerobically digested parthenium slurry. J. Photochem. Photobiol. B Biol. 2018, 183, 30-34. [CrossRef] [PubMed]

43. Etemadzade, M.; Ghamarypour, A.; Zabihollahi, R.; shabbak, G.; Shirazi, M.; Sahebjamee, H.; Vaziri, A.Z.; Assadi, A.; Ardestani, M.S.; Shandiz, S.A.S.; et al. Synthesis and evaluation of antiviral activities of novel sonochemical silver nanorods against hiv and hsv viruses. Asian Pac. J. Trop. Dis. 2016, 6, 854-858. [CrossRef]

44. Tamilselvan, S.; Ashokkumar, T.; Govindaraju, K. Microscopy based studies on the interaction of bio-based silver nanoparticles with bombyx mori nuclear polyhedrosis virus. J. Virol. Methods 2017, 242, 58-66. [CrossRef] [PubMed]

45. Kalaivani, R.; Maruthupandy, M.; Muneeswaran, T.; Hameedha Beevi, A.; Anand, M.; Ramakritinan, C.M.; Kumaraguru, A.K. Synthesis of chitosan mediated silver nanoparticles (Ag NPs) for potential antimicrobial applications. Front. Lab. Med. 2018, 2, 30-35. [CrossRef]

46. Dojčilović, R.; Pajović, J.D.; Božanić, D.K.; Bogdanović, U.; Vodnik, V.V.; Dimitrijević-Branković, S.; Miljković, M.G.; Kaščaková, S.; Réfrégiers, M.; Djoković, V. Interaction of amino acid-functionalized silver nanoparticles and Candida albicans polymorphs: A deep-UV fluorescence imaging study. Colloids Surf. B Biointerfaces 2017, 155, 341-348. [CrossRef] [PubMed]

47. Zhang, X.F.; Liu, Z.G.; Shen, W.; Gurunathan, S. Silver nanoparticles: Synthesis, characterization, properties, applications, and therapeutic approaches. Int. J. Mol. Sci. 2016, 17, 1534. [CrossRef] [PubMed]

48. Wei, L.; Lu, J.; Xu, H.; Patel, A.; Chen, Z.S.; Chen, G. Silver nanoparticles: Synthesis, properties, and therapeutic applications. Drug Discov. Today 2015, 20, 595-601. [CrossRef] [PubMed]

49. Singh, P.; Kim, Y.J.; Singh, H.; Wang, C.; Hwang, K.H.; Farh, M.E.-A.; Yang, D.C. Biosynthesis, characterization, and antimicrobial applications of silver nanoparticles. Int. J. Nanomed. 2015, 10, 2567-2577.

50. Mokhena, T.C.; Luyt, A.S. Electrospun alginate nanofibres impregnated with silver nanoparticles: Preparation, morphology and antibacterial properties. Carbohydr. Polym. 2017, 165, 304-312. [CrossRef] [PubMed]

51. Gudikandula, K.; Vadapally, P.; Singara Charya, M.A. Biogenic synthesis of silver nanoparticles from white rot fungi: Their characterization and antibacterial studies. OpenNano 2017, 2, 64-78. [CrossRef]

52. Guan, Q.; Xia, C.; Li, W. Bio-friendly controllable synthesis of silver nanoparticles and their enhanced antibacterial property. Catal. Today 2018. [CrossRef] 
53. Li, W.-R.; Sun, T.-L.; Zhou, S.-L.; Ma, Y.-K.; Shi, Q.-S.; Xie, X.-B.; Huang, X.-M. A comparative analysis of antibacterial activity, dynamics, and effects of silver ions and silver nanoparticles against four bacterial strains. Int. Biodeterior. Biodegrad. 2017, 123, 304-310. [CrossRef]

54. Premkumar, J.; Sudhakar, T.; Dhakal, A.; Shrestha, J.B.; Krishnakumar, S.; Balashanmugam, P. Synthesis of silver nanoparticles (AgNPs) from cinnamon against bacterial pathogens. Biocatal. Agric. Biotechnol. 2018, 15, 311-316. [CrossRef]

55. Shao, Y.; Wu, C.; Wu, T.; Yuan, C.; Chen, S.; Ding, T.; Ye, X.; Hu, Y. Green synthesis of sodium alginate-silver nanoparticles and their antibacterial activity. Int. J. Biol. Macromol. 2018, 111, 1281-1292. [CrossRef] [PubMed]

56. Yan, X.; He, B.; Liu, L.; Qu, G.; Shi, J.; Hu, L.; Jiang, G. Antibacterial mechanism of silver nanoparticles in pseudomonas aeruginosa: Proteomics approach. Metallomics 2018, 10, 557-564. [CrossRef] [PubMed]

57. Prabhu, S.; Poulose, E.K. Silver nanoparticles: Mechanism of antimicrobial action, synthesis, medical applications, and toxicity effects. Int. Nano Lett. 2012, 2, 32. [CrossRef]

58. López-Esparza, J.; Espinosa-Cristóbal, L.F.; Donohue-Cornejo, A.; Reyes-López, S.Y. Antimicrobial activity of silver nanoparticles in polycaprolactone nanofibers against gram-positive and gram-negative bacteria. Ind. Eng. Chem. Res. 2016, 55, 12532-12538. [CrossRef]

59. Bhat, R.; Deshpande, R.; Ganachari, S.V.; Huh, D.S.; Venkataraman, A. Photo-irradiated biosynthesis of silver nanoparticles using edible mushroom pleurotus florida and their antibacterial activity studies. Bioinorg. Chem. Appl. 2011, 2011, 650979. [CrossRef] [PubMed]

60. Izak-Nau, E.; Huk, A.; Reidy, B.; Uggerud, H.; Vadset, M.; Eiden, S.; Voetz, M.; Himly, M.; Duschl, A.; Dusinska, M.; et al. Impact of storage conditions and storage time on silver nanoparticles' physicochemical properties and implications for their biological effects. RSC Adv. 2015, 5, 84172-84185. [CrossRef]

61. Lee, J.-H.; Lim, J.-M.; Velmurugan, P.; Park, Y.-J.; Park, Y.-J.; Bang, K.-S.; Oh, B.-T. Photobiologic-mediated fabrication of silver nanoparticles with antibacterial activity. J. Photochem. Photobiol. B Biol. 2016, 162, 93-99. [CrossRef] [PubMed]

62. Ghiuță, I.; Cristea, D.; Croitoru, C.; Kost, J.; Wenkert, R.; Vyrides, I.; Anayiotos, A.; Munteanu, D. Characterization and antimicrobial activity of silver nanoparticles, biosynthesized using bacillus species. Appl. Surf. Sci. 2018, 438, 66-73. [CrossRef]

63. De Faria, A.F.; Martinez, D.S.T.; Meira, S.M.M.; de Moraes, A.C.M.; Brandelli, A.; Filho, A.G.S.; Alves, O.L. Anti-adhesion and antibacterial activity of silver nanoparticles supported on graphene oxide sheets. Colloids Surf. B Biointerfaces 2014, 113, 115-124. [CrossRef] [PubMed]

64. Zhou, Y.; Hu, K.; Guo, Z.; Fang, K.; Wang, X.; Yang, F.; Gu, N. Plla microcapsules combined with silver nanoparticles and chlorhexidine acetate showing improved antibacterial effect. Mater. Sci. Eng. C Mater. Biol. Appl. 2017, 78, 349-353. [CrossRef] [PubMed]

65. Amooaghaie, R.; Saeri, M.R.; Azizi, M. Synthesis, characterization and biocompatibility of silver nanoparticles synthesized from nigella sativa leaf extract in comparison with chemical silver nanoparticles. Ecotoxicol. Environ. Saf. 2015, 120, 400-408. [CrossRef] [PubMed]

66. Dakal, T.C.; Kumar, A.; Majumdar, R.S.; Yadav, V. Mechanistic basis of antimicrobial actions of silver nanoparticles. Front. Microbiol. 2016, 7, 1831. [CrossRef] [PubMed]

67. Majeed, S.; Danish, M.; Binti Zahrudin, A.H.; Dash, G.K. Biosynthesis and characterization of silver nanoparticles from fungal species and its antibacterial and anticancer effect. Karbala Int. J. Mod. Sci. 2018, 4, 86-92. [CrossRef]

68. Saravanan, M.; Arokiyaraj, S.; Lakshmi, T.; Pugazhendhi, A. Synthesis of silver nanoparticles from phenerochaete chrysosporium (MTCC-787) and their antibacterial activity against human pathogenic bacteria. Microb. Pathog. 2018, 117, 68-72. [CrossRef] [PubMed]

69. Dastafkan, K.; Khajeh, M.; Bohlooli, M.; Ghaffari-Moghaddam, M.; Sheibani, N. Mechanism and behavior of silver nanoparticles in aqueous medium as adsorbent. Talanta 2015, 144, 1377-1386. [CrossRef] [PubMed]

70. Lim, Y.H.; Tiemann, K.M.; Heo, G.S.; Wagers, P.O.; Rezenom, Y.H.; Zhang, S.; Zhang, F.; Youngs, W.J.; Hunstad, D.A.; Wooley, K.L. Preparation and in vitro antimicrobial activity of silver-bearing degradable polymeric nanoparticles of polyphosphoester-block-poly(L-lactide). ACS Nano 2015, 9, 1995-2008. [CrossRef] [PubMed]

71. Schneider, G. Antimicrobial silver nanoparticles-Regulatory situation in the European Union. Mater. Today Proc. 2017, 4, S200-S207. [CrossRef] 
72. Radzig, M.A.; Nadtochenko, V.A.; Koksharova, O.A.; Kiwi, J.; Lipasova, V.A.; Khmel, I.A. Antibacterial effects of silver nanoparticles on gram-negative bacteria: Influence on the growth and biofilms formation, mechanisms of action. Colloids Surf. B Biointerfaces 2013, 102, 300-306. [CrossRef] [PubMed]

73. Ribeiro, S.M.; Felicio, M.R.; Boas, E.V.; Goncalves, S.; Costa, F.F.; Samy, R.P.; Santos, N.C.; Franco, O.L. New frontiers for anti-biofilm drug development. Pharmacol. Ther. 2016, 160, 133-144. [CrossRef] [PubMed]

74. Barker, L.K.; Giska, J.R.; Radniecki, T.S.; Semprini, L. Effects of short- and long-term exposure of silver nanoparticles and silver ions to nitrosomonas europaea biofilms and planktonic cells. Chemosphere 2018, 206, 606-614. [CrossRef] [PubMed]

75. Joo, S.H.; Aggarwal, S. Factors impacting the interactions of engineered nanoparticles with bacterial cells and biofilms: Mechanistic insights and state of knowledge. J. Environ. Manag. 2018, 225, 62-74. [CrossRef] [PubMed]

76. Choi, Y.; Kim, H.-A.; Kim, K.-W.; Lee, B.-T. Comparative toxicity of silver nanoparticles and silver ions to Escherichia coli. J. Environ. Sci. 2018, 66, 50-60. [CrossRef] [PubMed]

77. Ramezanpour, M.; Leung, S.S.W.; Delgado-Magnero, K.H.; Bashe, B.Y.M.; Thewalt, J.; Tieleman, D.P. Computational and experimental approaches for investigating nanoparticle-based drug delivery systems. Biochim. Biophys. Acta (BBA) Biomembr. 2016, 1858, 1688-1709. [CrossRef] [PubMed]

78. Jahangirian, H.; Lemraski, E.G.; Webster, T.J.; Rafiee-Moghaddam, R.; Abdollahi, Y. A review of drug delivery systems based on nanotechnology and green chemistry: Green nanomedicine. Int. J. Nanomed. 2017, 12, 2957-2978. [CrossRef] [PubMed]

79. Jiang, Q.; Yu, S.; Li, X.; Ma, C.; Li, A. Evaluation of local anesthetic effects of lidocaine-ibuprofen ionic liquid stabilized silver nanoparticles in male swiss mice. J. Photochem. Photobiol. B Biol. 2018, 178, 367-370. [CrossRef] [PubMed]

80. Karthik, C.S.; Manukumar, H.M.; Ananda, A.P.; Nagashree, S.; Rakesh, K.P.; Mallesha, L.; Qin, H.-L.; Umesha, S.; Mallu, P.; Krishnamurthy, N.B. Synthesis of novel benzodioxane midst piperazine moiety decorated chitosan silver nanoparticle against biohazard pathogens and as potential anti-inflammatory candidate: A molecular docking studies. Int. J. Biol. Macromol. 2018, 108, 489-502. [CrossRef] [PubMed]

81. Soni, N.; Dhiman, R.C. Phytochemical, anti-oxidant, larvicidal, and antimicrobial activities of castor (Ricinus communis) synthesized silver nanoparticles. Chin. Herb. Med. 2017, 9, 289-294. [CrossRef]

82. Arumai Selvan, D.; Mahendiran, D.; Senthil Kumar, R.; Kalilur Rahiman, A. Garlic, green tea and turmeric extracts-mediated green synthesis of silver nanoparticles: Phytochemical, antioxidant and in vitro cytotoxicity studies. J. Photochem. Photobiol. B Biol. 2018, 180, 243-252. [CrossRef] [PubMed]

83. Al-Obaidi, H.; Kalgudi, R.; Zariwala, M.G. Fabrication of inhaled hybrid silver/ciprofloxacin nanoparticles with synergetic effect against pseudomonas aeruginosa. Eur. J. Pharm. Biopharm. 2018, 128, 27-35. [CrossRef] [PubMed]

84. Kaur, A.; Goyal, D.; Kumar, R. Surfactant mediated interaction of vancomycin with silver nanoparticles. Appl. Surf. Sci. 2018, 449, 23-30. [CrossRef]

85. Petrov, P.D.; Yoncheva, K.; Gancheva, V.; Konstantinov, S.; Trzebicka, B. Multifunctional block copolymer nanocarriers for co-delivery of silver nanoparticles and curcumin: Synthesis and enhanced efficacy against tumor cells. Eur. Polym. J. 2016, 81, 24-33. [CrossRef]

86. Tiwari, G.; Tiwari, R.; Sriwastawa, B.; Bhati, L.; Pandey, S.; Pandey, P.; Bannerjee, S.K. Drug delivery systems: An updated review. Int. J. Pharm. Investig. 2012, 2, 2-11. [CrossRef] [PubMed]

87. KJ, P. Multi-functional silver nanoparticles for drug delivery: A review. Int. J. Curr. Pharm. Rev. Res. 2017, 9, 1-5.

88. Tahseen, Q.A. Silver Nanoparticles as Drug Delivery Systems. Ph.D. Dissertations, Louisiana State University, Baton Rouge, LA, USA, 2013.

89. Anandhakumar, S.; Mahalakshmi, V.; Raichur, A.M. Silver nanoparticles modified nanocapsules for ultrasonically activated drug delivery. Mater. Sci. Eng. C 2012, 32, 2349-2355. [CrossRef]

90. Bagherzade, G.; Tavakoli, M.M.; Namaei, M.H. Green synthesis of silver nanoparticles using aqueous extract of saffron (Crocus satious L.) wastages and its antibacterial activity against six bacteria. Asian Pac. J. Trop. Biomed. 2017, 7, 227-233. [CrossRef]

91. Khadka, P.; Ro, J.; Kim, H.; Kim, I.; Kim, J.T.; Kim, H.; Cho, J.M.; Yun, G.; Lee, J. Pharmaceutical particle technologies: An approach to improve drug solubility, dissolution and bioavailability. Asian J. Pharm. Sci. 2014, 9, 304-316. [CrossRef] 
92. Kumar, B.; Jalodia, K.; Kumar, P.; Gautam, H.K. Recent advances in nanoparticle-mediated drug delivery. J. Drug Deliv. Sci. Technol. 2017, 41, 260-268. [CrossRef]

93. Venugopal, K.; Rather, H.A.; Rajagopal, K.; Shanthi, M.P.; Sheriff, K.; Illiyas, M.; Rather, R.A.; Manikandan, E.; Uvarajan, S.; Bhaskar, M.; et al. Synthesis of silver nanoparticles (Ag NPs) for anticancer activities (MCF 7 breast and A549 lung cell lines) of the crude extract of Syzygium aromaticum. J. Photochem. Photobiol. B Biol. 2017, 167, 282-289. [CrossRef] [PubMed]

94. Benyettou, F.; Rezgui, R.; Ravaux, F.; Jaber, T.; Blumer, K.; Jouiad, M.; Motte, L.; Olsen, J.C.; Platas-Iglesias, C.; Magzoub, M.; et al. Synthesis of silver nanoparticles for the dual delivery of doxorubicin and alendronate to cancer cells. J. Mater. Chem. B 2015, 3, 7237-7245. [CrossRef]

95. Barbinta-Patrascu, M.E.; Badea, N.; Pirvu, C.; Bacalum, M.; Ungureanu, C.; Nadejde, P.L.; Ion, C.; Rau, I. Multifunctional soft hybrid bio-platforms based on nano-silver and natural compounds. Mater. Sci. Eng. C 2016, 69, 922-932. [CrossRef] [PubMed]

96. Patra, S.; Mukherjee, S.; Barui, A.K.; Ganguly, A.; Sreedhar, B.; Patra, C.R. Green synthesis, characterization of gold and silver nanoparticles and their potential application for cancer therapeutics. Mater. Sci. Eng. C 2015, 53, 298-309. [CrossRef] [PubMed]

97. Ding, Q.; Liu, D.; Guo, D.; Yang, F.; Pang, X.; Che, R.; Zhou, N.; Xie, J.; Sun, J.; Huang, Z.; et al. Shape-controlled fabrication of magnetite silver hybrid nanoparticles with high performance magnetic hyperthermia. Biomaterials 2017, 124, 35-46. [CrossRef] [PubMed]

98. Poudel, B.K.; Soe, Z.C.; Ruttala, H.B.; Gupta, B.; Ramasamy, T.; Thapa, R.K.; Gautam, M.; Ou, W.; Nguyen, H.T.; Jeong, J.-H.; et al. In situ fabrication of mesoporous silica-coated silver-gold hollow nanoshell for remotely controllable chemo-photothermal therapy via phase-change molecule as gatekeepers. Int. J. Pharm. 2018, 548, 92-103. [CrossRef] [PubMed]

99. Díaz-Cruz, C.; Alonso Nuñez, G.; Espinoza-Gómez, H.; Flores-López, L.Z. Effect of molecular weight of peg or pva as reducing-stabilizing agent in the green synthesis of silver-nanoparticles. Eur. Polym. J. 2016, 83, $265-277$. [CrossRef]

100. Hefni, H.H.H.; Azzam, E.M.; Badr, E.A.; Hussein, M.; Tawfik, S.M. Synthesis, characterization and anticorrosion potentials of chitosan-g-peg assembled on silver nanoparticles. Int. J. Biol. Macromol. 2016, 83, 297-305. [CrossRef] [PubMed]

101. Yang, H.; Chen, T.; Wang, H.; Bai, S.; Guo, X. One-pot rapid synthesis of high aspect ratio silver nanowires for transparent conductive electrodes. Mater. Res. Bull. 2018, 102, 79-85. [CrossRef]

102. Gao, H.; Yang, H.; Wang, C. Controllable preparation and mechanism of nano-silver mediated by the microemulsion system of the clove oil. Results Phys. 2017, 7, 3130-3136. [CrossRef]

103. Rivera-Rangel, R.D.; González-Muñoz, M.P.; Avila-Rodriguez, M.; Razo-Lazcano, T.A.; Solans, C. Green synthesis of silver nanoparticles in oil-in-water microemulsion and nano-emulsion using geranium leaf aqueous extract as a reducing agent. Colloids Surf. A Physicochem. Eng. Asp. 2018, 536, 60-67. [CrossRef]

104. Clemente, A.; Moreno, N.; Lobera, M.P.; Balas, F.; Santamaria, J. Versatile hollow fluorescent metal-silica nanohybrids through a modified microemulsion synthesis route. J. Colloid Interface Sci. 2018, 513, 497-504. [CrossRef] [PubMed]

105. Hanh, T.T.; Thu, N.T.; Quoc, L.A.; Hien, N.Q. Synthesis and characterization of silver/diatomite nanocomposite by electron beam irradiation. Radiat. Phys. Chem. 2017, 139, 141-146. [CrossRef]

106. Dhayagude, A.C.; Das, A.; Joshi, S.S.; Kapoor, S. $\gamma$-radiation induced synthesis of silver nanoparticles in aqueous poly (N-vinylpyrrolidone) solution. Colloids Surf. A Physicochem. Eng. Asp. 2018, 556, 148-156. [CrossRef]

107. Zaheer, Z.; Aazam, E.S. Cetyltrimethylammonium bromide assisted synthesis of silver nanoparticles and their catalytic activity. J. Mol. Liq. 2017, 242, 1035-1041. [CrossRef]

108. Lopes, C.R.B.; Courrol, L.C. Green synthesis of silver nanoparticles with extract of mimusops coriacea and light. J. Lumin. 2018, 199, 183-187. [CrossRef]

109. Rai, M.; Ingle, A.P.; Gupta, I.; Brandelli, A. Bioactivity of noble metal nanoparticles decorated with biopolymers and their application in drug delivery. Int. J. Pharm. 2015, 496, 159-172. [CrossRef] [PubMed]

110. Sarkar, S.; Das, R. Shape effect on the optical properties of anisotropic silver nanocrystals. J. Lumin. 2018, 198, 464-470. [CrossRef] 
111. Delgado-Beleño, Y.; Martinez-Nuñez, C.E.; Cortez-Valadez, M.; Flores-López, N.S.; Flores-Acosta, M. Optical properties of silver, silver sulfide and silver selenide nanoparticles and antibacterial applications. Mater. Res. Bull. 2018, 99, 385-392. [CrossRef]

112. Dos Santos Courrol, D.; Regina Borges Lopes, C.; da Silva Cordeiro, T.; Regina Franzolin, M.; Dias Vieira Junior, N.; Elgul Samad, R.; Coronato Courrol, L. Optical properties and antimicrobial effects of silver nanoparticles synthesized by femtosecond laser photoreduction. Opt. Laser Technol. 2018, 103, 233-238. [CrossRef]

113. Brown, P.K.; Qureshi, A.T.; Moll, A.N.; Hayes, D.J.; Monroe, W.T. Silver nanoscale antisense drug delivery system for photoactivated gene silencing. ACS Nano 2013, 7, 2948-2959. [CrossRef] [PubMed]

114. Heilman, S.; Silva, L.G.A. Silver and titanium nanoparticles used as coating on polyurethane catheters. J. Nano Res. 2017, 47, 17-23. [CrossRef]

115. Thomas, R.; Mathew, S.; Nayana, A.R.; Mathews, J.; Radhakrishnan, E.K. Microbially and phytofabricated agnps with different mode of bactericidal action were identified to have comparable potential for surface fabrication of central venous catheters to combat staphylococcus aureus biofilm. J. Photochem. Photobiol. B Biol. 2017, 171, 96-103. [CrossRef] [PubMed]

116. Wu, K.; Yang, Y.; Zhang, Y.; Deng, J.; Lin, C. Antimicrobial activity and cytocompatibility of silver nanoparticles coated catheters via a biomimetic surface functionalization strategy. Int. J. Nanomed. 2015, 10, 7241-7252.

117. Roe, D.; Karandikar, B.; Bonn-Savage, N.; Gibbins, B.; Roullet, J.B. Antimicrobial surface functionalization of plastic catheters by silver nanoparticles. J. Antimicrob. Chemother. 2008, 61, 869-876. [CrossRef] [PubMed]

118. Kumar, C.G.; Sujitha, P. Green synthesis of kocuran-functionalized silver glyconanoparticles for use as antibiofilm coatings on silicone urethral catheters. Nanotechnology 2014, 25, 325101. [CrossRef] [PubMed]

119. Rtimi, S.; Sanjines, R.; Pulgarin, C.; Kiwi, J. Microstructure of cu-ag uniform nanoparticulate films on polyurethane 3D catheters: Surface properties. ACS Appl. Mater. Interfaces 2016, 8, 56-63. [CrossRef] [PubMed]

120. Ballottin, D.; Fulaz, S.; Cabrini, F.; Tsukamoto, J.; Durán, N.; Alves, O.L.; Tasic, L. Antimicrobial textiles: Biogenic silver nanoparticles against candida and xanthomonas. Mater. Sci. Eng. C 2017, 75, 582-589. [CrossRef] [PubMed]

121. Su, C.-H.; Kumar, G.V.; Adhikary, S.; Velusamy, P.; Pandian, K.; Anbu, P. Preparation of cotton fabric using sodium alginate-coated nanoparticles to protect against nosocomial pathogens. Biochem. Eng. J. 2017, 117, $28-35$. [CrossRef]

122. Zhang, M.; Lin, H.; Wang, Y.; Yang, G.; Zhao, H.; Sun, D. Fabrication and durable antibacterial properties of 3D porous wet electrospun rcsc/pcl nanofibrous scaffold with silver nanoparticles. Appl. Surf. Sci. 2017, 414, 52-62. [CrossRef]

123. Alippilakkotte, S.; Kumar, S.; Sreejith, L. Fabrication of pla/ag nanofibers by green synthesis method using momordica charantia fruit extract for wound dressing applications. Colloids Surf. A Physicochem. Eng. Asp. 2017, 529, 771-782. [CrossRef]

124. Li, R.; He, M.; Li, T.; Zhang, L. Preparation and properties of cellulose/silver nanocomposite fibers. Carbohydr. Polym. 2015, 115, 269-275. [CrossRef] [PubMed]

125. Biswas, P.; Bandyopadhyaya, R. Biofouling prevention using silver nanoparticle impregnated polyethersulfone (PES) membrane: E. coli cell-killing in a continuous cross-flow membrane module. J. Colloid Interface Sci. 2017, 491, 13-26. [CrossRef] [PubMed]

126. Benavente, J.; García, M.E.; Urbano, N.; López-Romero, J.M.; Contreras-Cáceres, R.C.; Casado-Rodríguez, M.A.; Moscoso, A.; Hierrezuelo, J. Inclusion of silver nanoparticles for improving regenerated cellulose membrane performance and reduction of biofouling. Int. J. Biol. Macromol. 2017, 103, 758-763. [CrossRef] [PubMed]

127. Štular, D.; Jerman, I.; Naglič, I.; Simončič, B.; Tomšič, B. Embedment of silver into temperature- and ph-responsive microgel for the development of smart textiles with simultaneous moisture management and controlled antimicrobial activities. Carbohydr. Polym. 2017, 159, 161-170. [CrossRef] [PubMed]

128. Ding, L.; Shan, X.; Zhao, X.; Zha, H.; Chen, X.; Wang, J.; Cai, C.; Wang, X.; Li, G.; Hao, J.; et al. Spongy bilayer dressing composed of chitosan-Ag nanoparticles and chitosan-Bletilla striata polysaccharide for wound healing applications. Carbohydr. Polym. 2017, 157, 1538-1547. [CrossRef] [PubMed] 
129. Stevens, K.N.; Crespo-Biel, O.; van den Bosch, E.E.; Dias, A.A.; Knetsch, M.L.; Aldenhoff, Y.B.; van der Veen, F.H.; Maessen, J.G.; Stobberingh, E.E.; Koole, L.H. The relationship between the antimicrobial effect of catheter coatings containing silver nanoparticles and the coagulation of contacting blood. Biomaterials 2009, 30, 3682-3690. [CrossRef] [PubMed]

130. Fufa, O.; Andronescu, E.; Grumezescu, V.; Holban, A.M.; Mogoanta, L.; Mogosanu, G.D.; Socol, G.; Iordache, F.; Chifiriuc, M.C.; Grumezescu, A.M. Silver nanostructurated surfaces prepared by maple for biofilm prevention. Biointerface Res. Appl. Chem. 2015, 5, 1011-1017.

131. Mala, R.; Annie Aglin, A.; Ruby Celsia, A.S.; Geerthika, S.; Kiruthika, N.; VazagaPriya, C.; Srinivasa Kumar, K. Foley catheters functionalised with a synergistic combination of antibiotics and silver nanoparticles resist biofilm formation. IET Nanobiotechnol. 2017, 11, 612-620. [CrossRef] [PubMed]

132. Jishma, P.; Narayanan, R.; Snigdha, S.; Thomas, R.; Radhakrishnan, E.K. Rapid degradative effect of microbially synthesized silver nanoparticles on textile dye in presence of sunlight. Biocatal. Agric. Biotechnol. 2018, 14, 410-417. [CrossRef]

133. Antonelli, M.; De Pascale, G.; Ranieri, V.M.; Pelaia, P.; Tufano, R.; Piazza, O.; Zangrillo, A.; Ferrario, A.; De Gaetano, A.; Guaglianone, E.; et al. Comparison of triple-lumen central venous catheters impregnated with silver nanoparticles $\left(\right.$ AgTive $\left.^{\circledR}\right)$ vs. conventional catheters in intensive care unit patients. J. Hosp. Infect. 2012, 82, 101-107. [CrossRef] [PubMed]

134. Stevens, K.N.J.; Croes, S.; Boersma, R.S.; Stobberingh, E.E.; van der Marel, C.; van der Veen, F.H.; Knetsch, M.L.W.; Koole, L.H. Hydrophilic surface coatings with embedded biocidal silver nanoparticles and sodium heparin for central venous catheters. Biomaterials 2011, 32, 1264-1269. [CrossRef] [PubMed]

135. Pollini, M.; Paladini, F.; Catalano, M.; Taurino, A.; Licciulli, A.; Maffezzoli, A.; Sannino, A. Antibacterial coatings on haemodialysis catheters by photochemical deposition of silver nanoparticles. J. Mater. Sci. Mater. Med. 2011, 22, 2005-2012. [CrossRef] [PubMed]

136. Aflori, M. Surface characterization of peritoneal dialysis catheter containing silver nanoparticles. Rev. Roum. Chim. 2014, 59, 523-526.

137. Ballo, M.K.; Rtimi, S.; Pulgarin, C.; Hopf, N.; Berthet, A.; Kiwi, J.; Moreillon, P.; Entenza, J.M.; Bizzini, A. In vitro and in vivo effectiveness of an innovative silver-copper nanoparticle coating of catheters to prevent methicillin-resistant staphylococcus aureus infection. Antimicrob. Agents Chemother. 2016, 60, 5349-5356. [CrossRef] [PubMed]

138. Dayyoub, E.; Frant, M.; Pinnapireddy, S.R.; Liefeith, K.; Bakowsky, U. Antibacterial and anti-encrustation biodegradable polymer coating for urinary catheter. Int. J. Pharm. 2017, 531, 205-214. [CrossRef] [PubMed]

139. Samuel, U.; Guggenbichler, J.P. Prevention of catheter-related infections: The potential of a new nano-silver impregnated catheter. Int. J. Antimicrob. Agents 2004, 23 (Suppl. 1), S75-S78. [CrossRef]

140. Cheng, L.; Zhang, K.; Weir, M.D.; Melo, M.A.; Zhou, X.; Xu, H.H. Nanotechnology strategies for antibacterial and remineralizing composites and adhesives to tackle dental caries. Nanomedicine 2015, 10, 627-641. [CrossRef] [PubMed]

141. Lee, D.; Lee, S.J.; Moon, J.-H.; Kim, J.H.; Heo, D.N.; Bang, J.B.; Lim, H.-N.; Kwon, I.K. Preparation of antibacterial chitosan membranes containing silver nanoparticles for dental barrier membrane applications. J. Ind. Eng. Chem. 2018. [CrossRef]

142. Divakar, D.D.; Jastaniyah, N.T.; Altamimi, H.G.; Alnakhli, Y.O.; Muzaheed; Alkheraif, A.A.; Haleem, S. Enhanced antimicrobial activity of naturally derived bioactive molecule chitosan conjugated silver nanoparticle against dental implant pathogens. Int. J. Biol. Macromol. 2018, 108, 790-797. [CrossRef] [PubMed]

143. Kaur, P.; Luthra, R. Silver nanoparticles in dentistry: An emerging trend. SRM J. Res. Dent. Sci. 2016, 7, $162-165$. [CrossRef]

144. Bapat, R.A.; Chaubal, T.V.; Joshi, C.P.; Bapat, P.R.; Choudhury, H.; Pandey, M.; Gorain, B.; Kesharwani, P. An overview of application of silver nanoparticles for biomaterials in dentistry. Mater. Sci. Eng. C 2018, 91, 881-898. [CrossRef] [PubMed]

145. Vogel, K.; Westphal, N.; Salz, D.; Thiel, K.; Wittig, L.; Ciacchi, L.C.; Grunwald, I. Dental implants coated with a durable and antibacterial film. Surf. Innov. 2015, 3, 27-38. [CrossRef]

146. Noronha, V.T.; Paula, A.J.; Durán, G.; Galembeck, A.; Cogo-Müller, K.; Franz-Montan, M.; Durán, N. Silver nanoparticles in dentistry. Dent. Mater. 2017, 33, 1110-1126. [CrossRef] [PubMed] 
147. Correa, J.M.; Mori, M.; Sanches, H.L.; da Cruz, A.D.; Poiate, E., Jr.; Poiate, I.A. Silver nanoparticles in dental biomaterials. Int. J. Biomater. 2015, 2015, 485275. [CrossRef] [PubMed]

148. Manikandan, V.; Velmurugan, P.; Park, J.H.; Chang, W.S.; Park, Y.J.; Jayanthi, P.; Cho, M.; Oh, B.T. Green synthesis of silver oxide nanoparticles and its antibacterial activity against dental pathogens. 3 Biotech 2017, 7, 72. [CrossRef] [PubMed]

149. Priyadarsini, S.; Mukherjee, S.; Mishra, M. Nanoparticles used in dentistry: A review. J. Oral Biol. Craniofac. Res. 2018, 8, 58-67. [CrossRef] [PubMed]

150. Zhang, N.; Melo, M.A.S.; Antonucci, J.M.; Lin, N.J.; Lin-Gibson, S.; Bai, Y.; Xu, H.H.K. Novel dental cement to combat biofilms and reduce acids for orthodontic applications to avoid enamel demineralization. Materials 2016, 9, 413. [CrossRef] [PubMed]

151. Nguyen, S.; Hiorth, M. Advanced drug delivery systems for local treatment of the oral cavity. Ther. Deliv. 2015, 6, 595-608. [CrossRef] [PubMed]

152. Elias Santos, V.; Targino, A.; Pelagio Flores, M.A.; de Luna Freire Pessoa, H.; Galembeck, A.; Rosenblatt, A. Antimicrobial activity of silver nanoparticles in treating dental caries. RFO 2014, 18, 312-315. [CrossRef]

153. Chambers, C.; Stewart, S.B.; Su, B.; Jenkinson, H.F.; Sandy, J.R.; Ireland, A.J. Silver doped titanium dioxide nanoparticles as antimicrobial additives to dental polymers. Dent. Mater. 2017, 33, e115-e123. [CrossRef] [PubMed]

154. Mahross, H.Z.; Baroudi, K. Effect of silver nanoparticles incorporation on viscoelastic properties of acrylic resin denture base material. Eur. J. Dent. 2015, 9, 207-212. [PubMed]

155. Pokrowiecki, R.; Zareba, T.; Szaraniec, B.; Palka, K.; Mielczarek, A.; Menaszek, E.; Tyski, S. In vitro studies of nanosilver-doped titanium implants for oral and maxillofacial surgery. Int. J. Nanomed. 2017, 12, 4285-4297. [CrossRef] [PubMed]

156. Lee, S.J.; Heo, M.; Lee, D.; Han, S.; Moon, J.-H.; Lim, H.-N.; Kwon, I.K. Preparation and characterization of antibacterial orthodontic resin containing silver nanoparticles. Appl. Surf. Sci. 2018, 432, 317-323. [CrossRef]

157. Ai, M.; Du, Z.; Zhu, S.; Geng, H.; Zhang, X.; Cai, Q.; Yang, X. Composite resin reinforced with silver nanoparticles-laden hydroxyapatite nanowires for dental application. Dent. Mater. 2017, 33, $12-22$. [CrossRef] [PubMed]

158. Paiva, L.; Fidalgo, T.K.S.; da Costa, L.P.; Maia, L.C.; Balan, L.; Anselme, K.; Ploux, L.; Thiré, R.M.S.M. Antibacterial properties and compressive strength of new one-step preparation silver nanoparticles in glass ionomer cements (NanoAg-GIC). J. Dent. 2018, 69, 102-109. [CrossRef] [PubMed]

159. Slane, J.; Vivanco, J.; Rose, W.; Ploeg, H.-L.; Squire, M. Mechanical, material, and antimicrobial properties of acrylic bone cement impregnated with silver nanoparticles. Mater. Sci. Eng. C 2015, 48, 188-196. [CrossRef] [PubMed]

160. Freire, P.L.L.; Albuquerque, A.J.R.; Farias, I.A.P.; da Silva, T.G.; Aguiar, J.S.; Galembeck, A.; Flores, M.A.P.; Sampaio, F.C.; Stamford, T.C.M.; Rosenblatt, A. Antimicrobial and cytotoxicity evaluation of colloidal chitosan-Silver nanoparticles-Fluoride nanocomposites. Int. J. Biol. Macromol. 2016, 93, 896-903. [CrossRef] [PubMed]

161. Wang, J.; Dong, X.; Yu, Q.; Baker, S.N.; Li, H.; Larm, N.E.; Baker, G.A.; Chen, L.; Tan, J.; Chen, M. Incorporation of antibacterial agent derived deep eutectic solvent into an active dental composite. Dent. Mater. 2017, 33, 1445-1455. [CrossRef] [PubMed]

162. Natale, L.C.; Alania, Y.; Rodrigues, M.C.; Simões, A.; de Souza, D.N.; de Lima, E.; Arana-Chavez, V.E.; Hewer, T.L.R.; Hiers, R.; Esteban-Florez, F.L.; et al. Synthesis and characterization of silver phosphate/calcium phosphate mixed particles capable of silver nanoparticle formation by photoreduction. Mater. Sci. Eng. C 2017, 76, 464-471. [CrossRef] [PubMed]

163. Gunputh, U.F.; Le, H.; Handy, R.D.; Tredwin, C. Anodised $\mathrm{TiO}_{2}$ nanotubes as a scaffold for antibacterial silver nanoparticles on titanium implants. Mater. Sci. Eng. C 2018, 91, 638-644. [CrossRef] [PubMed]

164. Ferraris, S.; Spriano, S.; Miola, M.; Bertone, E.; Allizond, V.; Cuffini, A.M.; Banche, G. Surface modification of titanium surfaces through a modified oxide layer and embedded silver nanoparticles: Effect of reducing/stabilizing agents on precipitation and properties of the nanoparticles. Surf. Coat. Technol. 2018, 344, 177-189. [CrossRef]

165. Garcia-Contreras, R.; Argueta-Figueroa, L.; Mejia-Rubalcava, C.; Jimenez-Martinez, R.; Cuevas-Guajardo, S.; Sanchez-Reyna, P.A.; Mendieta-Zeron, H. Perspectives for the use of silver nanoparticles in dental practice. Int. Dent. J. 2011, 61, 297-301. [CrossRef] [PubMed] 
166. Wilkinson, L.J.; White, R.J.; Chipman, J.K. Silver and nanoparticles of silver in wound dressings: A review of efficacy and safety. J. Wound Care 2011, 20, 543-549. [CrossRef] [PubMed]

167. Chowdhury, S.; De, M.; Guha, R.; Batabyal, S.; Samanta, I.; Hazra Samir, K.; Ghosh Tamal, K.; Konar, A.; Hazra, S. Influence of silver nanoparticles on post-surgical wound healing following topical application. Eur. J. Nanomed. 2014, 6, 237. [CrossRef]

168. You, C.; Li, Q.; Wang, X.; Wu, P.; Ho, J.K.; Jin, R.; Zhang, L.; Shao, H.; Han, C. Silver nanoparticle loaded collagen/chitosan scaffolds promote wound healing via regulating fibroblast migration and macrophage activation. Sci. Rep. 2017, 7, 10489. [CrossRef] [PubMed]

169. Zulkifli, F.H.; Hussain, F.S.J.; Zeyohannes, S.S.; Rasad, M.S.B.A.; Yusuff, M.M. A facile synthesis method of hydroxyethyl cellulose-silver nanoparticle scaffolds for skin tissue engineering applications. Mater. Sci. Eng. C 2017, 79, 151-160. [CrossRef] [PubMed]

170. Gong, C.P.; Li, S.C.; Wang, R.Y. Development of biosynthesized silver nanoparticles based formulation for treating wounds during nursing care in hospitals. J. Photochem. Photobiol. B Biol. 2018, 183, 137-141. [CrossRef] [PubMed]

171. Hendi, A. Silver nanoparticles mediate differential responses in some of liver and kidney functions during skin wound healing. J. King Saud Univ. Sci. 2011, 23, 47-52. [CrossRef]

172. Hebeish, A.; El-Rafie, M.H.; El-Sheikh, M.A.; Seleem, A.A.; El-Naggar, M.E. Antimicrobial wound dressing and anti-inflammatory efficacy of silver nanoparticles. Int. J. Biol. Macromol. 2014, 65, 509-515. [CrossRef] [PubMed]

173. Konop, M.; Damps, T.; Misicka, A.; Rudnicka, L. Certain aspects of silver and silver nanoparticles in wound care: A minireview. J. Nanomater. 2016, 2016, 7614753. [CrossRef]

174. Yang, Y.; Hu, H. A review on antimicrobial silver absorbent wound dressings applied to exuding wounds. J. Microb. Biochem. Technol. 2015, 7, 228-233.

175. Larese, F.F.; D'Agostin, F.; Crosera, M.; Adami, G.; Renzi, N.; Bovenzi, M.; Maina, G. Human skin penetration of silver nanoparticles through intact and damaged skin. Toxicology 2009, 255, 33-37. [CrossRef] [PubMed]

176. Abdelgawad, A.M.; Hudson, S.M.; Rojas, O.J. Antimicrobial wound dressing nanofiber mats from multicomponent (chitosan/silver-NPs/polyvinyl alcohol) systems. Carbohydr. Polym. 2014, 100, 166-178. [CrossRef] [PubMed]

177. Cardoso, V.S.; de Carvalho Filgueiras, M.; Dutra, Y.M.; Teles, R.H.G.; de Araujo, A.R.; Primo, F.L.; Mafud, A.C.; Batista, L.F.; Mascarenhas, Y.P.; Paino, I.M.M.; et al. Collagen-based silver nanoparticles: Study on cell viability, skin permeation, and swelling inhibition. Mater. Sci. Eng. C Mater. Biol. Appl. 2017, 74, 382-388. [CrossRef] [PubMed]

178. Kumar, S.S.D.; Rajendran, N.K.; Houreld, N.N.; Abrahamse, H. Recent advances on silver nanoparticle and biopolymer-based biomaterials for wound healing applications. Int. J. Biol. Macromol. 2018, 115, 165-175. [CrossRef] [PubMed]

179. Bozaci, E.; Akar, E.; Ozdogan, E.; Demir, A.; Altinisik, A.; Seki, Y. Application of carboxymethylcellulose hydrogel based silver nanocomposites on cotton fabrics for antibacterial property. Carbohydr. Polym. 2015, 134, 128-135. [CrossRef] [PubMed]

180. Emam, H.E.; Saleh, N.H.; Nagy, K.S.; Zahran, M.K. Functionalization of medical cotton by direct incorporation of silver nanoparticles. Int. J. Biol. Macromol. 2015, 78, 249-256. [CrossRef] [PubMed]

181. Li, Z.; Wang, L.; Chen, S.; Feng, C.; Chen, S.; Yin, N.; Yang, J.; Wang, H.; Xu, Y. Facilely green synthesis of silver nanoparticles into bacterial cellulose. Cellulose 2015, 22, 373-383. [CrossRef]

182. Shao, W.; Liu, H.; Liu, X.; Sun, H.; Wang, S.; Zhang, R. Ph-responsive release behavior and anti-bacterial activity of bacterial cellulose-silver nanocomposites. Int. J. Biol. Macromol. 2015, 76, 209-217. [CrossRef] [PubMed]

183. Martins, A.F.; Monteiro, J.P.; Bonafé, E.G.; Gerola, A.P.; Silva, C.T.P.; Girotto, E.M.; Rubira, A.F.; Muniz, E.C. Bactericidal activity of hydrogel beads based on $N, N, N$-trimethyl chitosan/alginate complexes loaded with silver nanoparticles. Chin. Chem. Lett. 2015, 26, 1129-1132. [CrossRef]

184. Eghbalifam, N.; Frounchi, M.; Dadbin, S. Antibacterial silver nanoparticles in polyvinyl alcohol/sodium alginate blend produced by gamma irradiation. Int. J. Biol. Macromol. 2015, 80, 170-176. [CrossRef] [PubMed]

185. Zhao, X.; Li, Q.; Ma, X.; Quan, F.; Wang, J.; Xia, Y. The preparation of alginate-AgNPs composite fiber with green approach and its antibacterial activity. J. Ind. Eng. Chem. 2015, 24, 188-195. [CrossRef] 
186. Mishra, M.; Kumar, H.; Tripathi, K. Diabetic delayed wound healing and the role of silver nanoparticles. Dig. J. Nanomater. Bios. 2008, 3, 49-54.

187. Rigo, C.; Ferroni, L.; Tocco, I.; Roman, M.; Munivrana, I.; Gardin, C.; Cairns, W.R.L.; Vindigni, V.; Azzena, B.; Barbante, C.; et al. Active silver nanoparticles for wound healing. Int. J. Mol. Sci. 2013, 14, 4817-4840. [CrossRef] [PubMed]

188. Correia, T.R.; Figueira, D.R.; de Sá, K.D.; Miguel, S.P.; Fradique, R.G.; Mendonça, A.G.; Correia, I.J. 3D printed scaffolds with bactericidal activity aimed for bone tissue regeneration. Int. J. Biol. Macromol. 2016, 93, 1432-1445. [CrossRef] [PubMed]

189. Castiglioni, S.; Cazzaniga, A.; Locatelli, L.; Maier, J.A.M. Silver nanoparticles in orthopedic applications: New insights on their effects on osteogenic cells. Nanomaterials 2017, 7, 124. [CrossRef] [PubMed]

190. Ralston, S.H. Bone structure and metabolism. Medicine 2013, 41, 581-585. [CrossRef]

191. Zhang, Y.; Zhai, D.; Xu, M.; Yao, Q.; Zhu, H.; Chang, J.; Wu, C. 3D-printed bioceramic scaffolds with antibacterial and osteogenic activity. Biofabrication 2017, 9, 025037. [CrossRef] [PubMed]

192. Aurore, V.; Caldana, F.; Blanchard, M.; Kharoubi Hess, S.; Lannes, N.; Mantel, P.Y.; Filgueira, L.; Walch, M. Silver-nanoparticles increase bactericidal activity and radical oxygen responses against bacterial pathogens in human osteoclasts. Nanomed. Nanotechnol. Biol. Med. 2018, 14, 601-607. [CrossRef] [PubMed]

193. Qing, T.; Mahmood, M.; Zheng, Y.; Biris, A.S.; Shi, L.; Casciano, D.A. A genomic characterization of the influence of silver nanoparticles on bone differentiation in MC3T3-E1 cells. J. Appl. Toxicol. JAT 2018, 38, 172-179. [CrossRef] [PubMed]

194. Brennan, S.A.; Ni Fhoghlu, C.; Devitt, B.M.; O’Mahony, F.J.; Brabazon, D.; Walsh, A. Silver nanoparticles and their orthopaedic applications. Bone Jt. J. 2015, 97-B, 582-589. [CrossRef] [PubMed]

195. Lu, H.; Liu, Y.; Guo, J.; Wu, H.; Wang, J.; Wu, G. Biomaterials with antibacterial and osteoinductive properties to repair infected bone defects. Int. J. Mol. Sci. 2016, 17, 334. [CrossRef] [PubMed]

196. Bharti, A.; Singh, S.; Meena, V.K.; Goyal, N. Structural characterization of silver-hydroxyapatite nanocomposite: A bone repair biomaterial. Mater. Today Proc. 2016, 3, 2113-2120. [CrossRef]

197. Lim, P.N.; Chang, L.; Thian, E.S. Development of nanosized silver-substituted apatite for biomedical applications: A review. Nanomed. Nanotechnol. Biol. Med. 2015, 11, 1331-1344. [CrossRef] [PubMed]

198. Lazić, V.; Smičiklas, I.; Marković, J.; Lončarević, D.; Dostanić, J.; Ahrenkiel, S.P.; Nedeljković, J.M. Antibacterial ability of supported silver nanoparticles by functionalized hydroxyapatite with 5-aminosalicylic acid. Vacuum 2018, 148, 62-68. [CrossRef]

199. Fu, C.; Zhang, X.; Savino, K.; Gabrys, P.; Gao, Y.; Chaimayo, W.; Miller, B.L.; Yates, M.Z. Antimicrobial silver-hydroxyapatite composite coatings through two-stage electrochemical synthesis. Surf. Coat. Technol. 2016, 301, 13-19. [CrossRef]

200. Andrade, F.A.C.; de Oliveira Vercik, L.C.; Monteiro, F.J.; da Silva Rigo, E.C. Preparation, characterization and antibacterial properties of silver nanoparticles-hydroxyapatite composites by a simple and eco-friendly method. Ceram. Int. 2016, 42, 2271-2280. [CrossRef]

201. Yu, W.-Z.; Zhang, Y.; Liu, X.; Xiang, Y.; Li, Z.; Wu, S. Synergistic antibacterial activity of multi components in lysozyme/chitosan/silver/hydroxyapatite hybrid coating. Mater. Des. 2018, 139, 351-362. [CrossRef]

202. Zhang, X.; Chaimayo, W.; Yang, C.; Yao, J.; Miller, B.L.; Yates, M.Z. Silver-hydroxyapatite composite coatings with enhanced antimicrobial activities through heat treatment. Surf. Coat. Technol. 2017, 325, 39-45. [CrossRef]

203. Geng, Z.; Wang, R.; Zhuo, X.; Li, Z.; Huang, Y.; Ma, L.; Cui, Z.; Zhu, S.; Liang, Y.; Liu, Y.; et al. Incorporation of silver and strontium in hydroxyapatite coating on titanium surface for enhanced antibacterial and biological properties. Mater. Sci. Eng. C 2017, 71, 852-861. [CrossRef] [PubMed]

204. Mirzaee, M.; Vaezi, M.; Palizdar, Y. Synthesis and characterization of silver doped hydroxyapatite nanocomposite coatings and evaluation of their antibacterial and corrosion resistance properties in simulated body fluid. Mater. Sci. Eng. C 2016, 69, 675-684. [CrossRef] [PubMed]

205. Zhou, K.; Dong, C.; Zhang, X.; Shi, L.; Chen, Z.; Xu, Y.; Cai, H. Preparation and characterization of nanosilver-doped porous hydroxyapatite scaffolds. Ceram. Int. 2015, 41, 1671-1676. [CrossRef]

206. Ciobanu, C.S.; Iconaru, S.L.; Pasuk, I.; Vasile, B.S.; Lupu, A.R.; Hermenean, A.; Dinischiotu, A.; Predoi, D. Structural properties of silver doped hydroxyapatite and their biocompatibility. Mater. Sci. Eng. C 2013, 33, 1395-1402. [CrossRef] [PubMed] 
207. Ciobanu, G.; Ilisei, S.; Luca, C. Hydroxyapatite-silver nanoparticles coatings on porous polyurethane scaffold. Mater. Sci. Eng. C 2014, 35, 36-42. [CrossRef] [PubMed]

208. Jin, G.; Qin, H.; Cao, H.; Qian, S.; Zhao, Y.; Peng, X.; Zhang, X.; Liu, X.; Chu, P.K. Synergistic effects of dual zn/ag ion implantation in osteogenic activity and antibacterial ability of titanium. Biomaterials 2014, 35, 7699-7713. [CrossRef] [PubMed]

209. Hasan, A.; Waibhaw, G.; Saxena, V.; Pandey, L.M. Nano-biocomposite scaffolds of chitosan, carboxymethyl cellulose and silver nanoparticle modified cellulose nanowhiskers for bone tissue engineering applications. Int. J. Biol. Macromol. 2018, 111, 923-934. [CrossRef] [PubMed]

210. Strydom, S.J.; Rose, W.E.; Otto, D.P.; Liebenberg, W.; De Villiers, M.M. Poly(amidoamine) dendrimer-mediated synthesis and stabilization of silver sulfonamide nanoparticles with increased antibacterial activity. Nanomedicine 2013, 9, 85-93. [CrossRef] [PubMed]

211. González-Sánchez, M.I.; Perni, S.; Tommasi, G.; Morris, N.G.; Hawkins, K.; López-Cabarcos, E.; Prokopovich, P. Silver nanoparticle based antibacterial methacrylate hydrogels potential for bone graft applications. Mater. Sci. Eng. C 2015, 50, 332-340. [CrossRef] [PubMed]

212. Zhang, R.; Lee, P.; Lui, V.C.; Chen, Y.; Liu, X.; Lok, C.N.; To, M.; Yeung, K.W.; Wong, K.K. Silver nanoparticles promote osteogenesis of mesenchymal stem cells and improve bone fracture healing in osteogenesis mechanism mouse model. Nanomed. Nanotechnol. Biol. Med. 2015, 11, 1949-1959. [CrossRef] [PubMed]

213. Pauksch, L.; Hartmann, S.; Rohnke, M.; Szalay, G.; Alt, V.; Schnettler, R.; Lips, K. Biocompatibility of silver nanoparticles and silver ions in primary human mesenchymal stem cells and osteoblasts. Acta Biomater. 2013, 10, 439-449. [CrossRef] [PubMed]

214. De Sá, K.D.; Figueira, D.R.; Miguel, S.P.; Correia, T.R.; Silva, A.P.; Correia, I.J. 3D scaffolds coated with nanofibers displaying bactericidal activity for bone tissue applications. Int. J. Polym. Mater. Polym. Biomater. 2017, 66, 432-442. [CrossRef]

215. Thapa, R.K.; Kim, J.H.; Jeong, J.H.; Shin, B.S.; Choi, H.G.; Yong, C.S.; Kim, J.O. Silver nanoparticle-embedded graphene oxide-methotrexate for targeted cancer treatment. Colloids Surf. B Biointerfaces 2017, 153, 95-103. [CrossRef] [PubMed]

216. Rajeshkumar, S.; Malarkodi, C.; Vanaja, M.; Annadurai, G. Anticancer and enhanced antimicrobial activity of biosynthesizd silver nanoparticles against clinical pathogens. J. Mol. Struct. 2016, 1116, 165-173. [CrossRef]

217. Pongrac, I.M.; Ahmed, L.B.; Mlinarić, H.; Jurašin, D.D.; Pavičić, I.; Marjanović Čermak, A.M.; Milić, M.; Gajović, S.; Vinković Vrček, I. Surface coating affects uptake of silver nanoparticles in neural stem cells. J. Trace Elem. Med. Biol. 2017. [CrossRef] [PubMed]

218. Mattea, F.; Vedelago, J.; Malano, F.; Gomez, C.; Strumia, M.; Valente, M. Silver nanoparticles in X-ray biomedical applications. Radiat. Phys. Chem. 2017, 130, 442-450. [CrossRef]

219. Vedelago, J.; Gomez, C.G.; Valente, M.; Mattea, F. Green synthesis of silver nanoparticles aimed at improving theranostics. Radiat. Phys. Chem. 2018, 146, 55-67. [CrossRef]

220. Sharma, H.; Mishra, P.K.; Talegaonkar, S.; Vaidya, B. Metal nanoparticles: A theranostic nanotool against cancer. Drug Discov. Today 2015, 20, 1143-1151. [CrossRef] [PubMed]

221. Jiang, W.; Rutherford, D.; Vuong, T.; Liu, H. Nanomaterials for treating cardiovascular diseases: A review. Bioact. Mater. 2017, 2, 185-198. [CrossRef] [PubMed]

222. Gonzalez, C.; Rosas-Hernandez, H.; Ramirez-Lee, M.A.; Salazar-Garcia, S.; Ali, S.F. Role of silver nanoparticles (AgNPs) on the cardiovascular system. Arch. Toxicol. 2016, 90, 493-511. [CrossRef] [PubMed]

223. Ramirez-Lee, M.A.; Aguirre-Banuelos, P.; Martinez-Cuevas, P.P.; Espinosa-Tanguma, R.; Chi-Ahumada, E.; Martinez-Castanon, G.A.; Gonzalez, C. Evaluation of cardiovascular responses to silver nanoparticles (AgNPs) in spontaneously hypertensive rats. Nanomed. Nanotechnol. Biol. Med. 2018, 14, 385-395. [CrossRef] [PubMed]

224. Ge, L.; Li, Q.; Wang, M.; Ouyang, J.; Li, X.; Xing, M.M.Q. Nanosilver particles in medical applications: Synthesis, performance, and toxicity. Int. J. Nanomed. 2014, 9, 2399-2407.

225. Rai, M.; Ingle, A.P.; Paralikar, P.; Gupta, I.; Medici, S.; Santos, C.A. Recent advances in use of silver nanoparticles as antimalarial agents. Int. J. Pharm. 2017, 526, 254-270. [CrossRef] [PubMed]

226. Chakrabarti, S.; Islam, J.; Hazarika, H.; Mazumder, B.; Raju, P.S.; Chattopadhyay, P. Safety profile of silver sulfadiazine-bfgf-loaded hydrogel for partial thickness burn wounds. Cutan. Ocul. Toxicol. 2018, 37, 258-266. [CrossRef] [PubMed] 
227. Sung, A.Y.; Kim, T.-H. Physical properties of ophthalmic hydrogel polymer containing zinc oxide nanoparticles. J. Chosun Nat. Sci. 2013, 6, 76-81. [CrossRef]

228. Söderstjerna, E.; Bauer, P.; Cedervall, T.; Abdshill, H.; Johansson, F.; Johansson, U.E. Silver and gold nanoparticles exposure to in vitro cultured retina-Studies on nanoparticle internalization, apoptosis, oxidative stress, glial- and microglial activity. PLoS ONE 2014, 9, e105359. [CrossRef] [PubMed]

229. Weng, Y.; Liu, J.; Jin, S.; Guo, W.; Liang, X.; Hu, Z. Nanotechnology-based strategies for treatment of ocular disease. Acta Pharm. Sin. B 2017, 7, 281-291. [CrossRef] [PubMed]

230. Yee, W.; Selvaduray, G.; Hawkins, B. Characterization of silver nanoparticle-infused tissue adhesive for ophthalmic use. J. Mech. Behav. Biomed. Mater. 2016, 55, 67-74. [CrossRef] [PubMed]

231. Rizzello, L.; Pompa, P.P. Nanosilver-based antibacterial drugs and devices: Mechanisms, methodological drawbacks, and guidelines. Chem. Soc. Rev. 2014, 43, 1501-1518. [CrossRef] [PubMed]

232. Pind’áková, L.; Kašpárková, V.; Kejlová, K.; Dvořáková, M.; Krsek, D.; Jírová, D.; Kašparová, L. Behaviour of silver nanoparticles in simulated saliva and gastrointestinal fluids. Int. J. Pharm. 2017, 527, 12-20. [CrossRef] [PubMed]

233. Rai, M.; Kon, K.; Ingle, A.; Duran, N.; Galdiero, S.; Galdiero, M. Broad-spectrum bioactivities of silver nanoparticles: The emerging trends and future prospects. Appl. Microbiol. Biotechnol. 2014, 98, 1951-1961. [CrossRef] [PubMed]

234. Hadrup, N.; Lam, H.R. Oral toxicity of silver ions, silver nanoparticles and colloidal silver-A review. Regul. Toxicol. Pharmacol. 2014, 68, 1-7. [CrossRef] [PubMed]

235. Vazquez-Munoz, R.; Borrego, B.; Juarez-Moreno, K.; Garcia-Garcia, M.; Mota Morales, J.D.; Bogdanchikova, N.; Huerta-Saquero, A. Toxicity of silver nanoparticles in biological systems: Does the complexity of biological systems matter? Toxicol. Lett. 2017, 276, 11-20. [CrossRef] [PubMed]

236. Salarian, A.A.; Bahari, Y.; Hami, Z.; Soltani-Rezaee-Rad, M. Cephalexin nanoparticles: Synthesis, cytotoxicity and their synergistic antibacterial study in combination with silver nanoparticles. Mater. Chem. Phys. 2017, 198, 125-130. [CrossRef]

237. Stensberg, M.C.; Wei, Q.; McLamore, E.S.; Porterfield, D.M.; Wei, A.; Sepúlveda, M.S. Toxicological studies on silver nanoparticles: Challenges and opportunities in assessment, monitoring and imaging. Nanomedicine 2011, 6, 879-898. [CrossRef] [PubMed]

238. Mohamed El Mahdy, M.; Salah, T.; Sayed Aly, H.; Mohammed, F.; Shaalan, M. Evaluation of hepatotoxic and genotoxic potential of silver nanoparticles in albino rats. Exp. Toxicol. Pathol. 2015, 67, 21-29. [CrossRef] [PubMed]

239. Pinzaru, I.; Coricovac, D.; Dehelean, C.; Moaca, E.A.; Mioc, M.; Baderca, F.; Sizemore, I.; Brittle, S.; Marti, D.; Calina, C.D.; et al. Stable peg-coated silver nanoparticles-A comprehensive toxicological profile. Food Chem. Toxicol. 2018, 111, 546-556. [CrossRef] [PubMed]

240. Jacob, J.A.; Sivalingam, P.; Chen, B. Toxicological effects of silver nanoparticles. Environ. Toxicol. Pharmacol. 2015, 40, 729-732.

241. Franci, G.; Falanga, A.; Galdiero, S.; Palomba, L.; Rai, M.; Morelli, G.; Galdiero, M. Silver nanoparticles as potential antibacterial agents. Molecules 2015, 20, 8856-8874. [CrossRef] [PubMed]

242. Wu, F.; Harper, B.J;; Harper, S.L. Differential dissolution and toxicity of surface functionalized silver nanoparticles in small-scale microcosms: Impacts of community complexity. Environ. Sci. Nano 2017, 4, 359-372. [CrossRef]

243. Dubey, P.; Matai, I.; Kumar, S.U.; Sachdev, A.; Bhushan, B.; Gopinath, P. Perturbation of cellular mechanistic system by silver nanoparticle toxicity: Cytotoxic, genotoxic and epigenetic potentials. Adv. Colloid Interface Sci. 2015, 221, 4-21. [CrossRef] [PubMed]

244. Ribeiro, A.P.C.; Anbu, S.; Alegria, E.; Fernandes, A.R.; Baptista, P.V.; Mendes, R.; Matias, A.S.; Mendes, M.; Guedes da Silva, M.F.C.; Pombeiro, A.J.L. Evaluation of cell toxicity and DNA and protein binding of green synthesized silver nanoparticles. Biomed. Pharmacother. 2018, 101, 137-144. [CrossRef] [PubMed]

245. Lin, C.X.; Yang, S.Y.; Gu, J.L.; Meng, J.; Xu, H.Y.; Cao, J.M. The acute toxic effects of silver nanoparticles on myocardial transmembrane potential, ina and ik1 channels and heart rhythm in mice. Nanotoxicology 2017, 11, 827-837. [CrossRef] [PubMed]

246. McShan, D.; Ray, P.C.; Yu, H. Molecular toxicity mechanism of nanosilver. J. Food Drug Anal. 2014, 22, $116-127$. [CrossRef] [PubMed] 
247. Senthil, B.; Devasena, T.; Prakash, B.; Rajasekar, A. Non-cytotoxic effect of green synthesized silver nanoparticles and its antibacterial activity. J. Photochem. Photobiol. B Biol. 2017, 177, 1-7. [CrossRef] [PubMed]

248. Kora, A.J.; Sashidhar, R.B. Biogenic silver nanoparticles synthesized with rhamnogalacturonan gum: Antibacterial activity, cytotoxicity and its mode of action. Arab. J. Chem. 2018, 11, 313-323. [CrossRef]

249. Dos Santos, C.A.; Seckler, M.M.; Ingle, A.P.; Gupta, I.; Galdiero, S.; Galdiero, M.; Gade, A.; Rai, M. Silver nanoparticles: Therapeutical uses, toxicity, and safety issues. J. Pharm. Sci. 2014, 103, 1931-1944. [CrossRef] [PubMed]

250. Sudha, A.; Jeyakanthan, J.; Srinivasan, P. Green synthesis of silver nanoparticles using lippia nodiflora aerial extract and evaluation of their antioxidant, antibacterial and cytotoxic effects. Resour-Effic. Technol. 2017, 3, 506-515. [CrossRef]

251. Furno, F.; Morley, K.S.; Wong, B.; Sharp, B.L.; Arnold, P.L.; Howdle, S.M.; Bayston, R.; Brown, P.D.; Winship, P.D.; Reid, H.J. Silver nanoparticles and polymeric medical devices: A new approach to prevention of infection? J. Antimicrob. Chemother. 2004, 54, 1019-1024. [CrossRef] [PubMed]

252. Gliga, A.R.; Skoglund, S.; Odnevall Wallinder, I.; Fadeel, B.; Karlsson, H.L. Size-dependent cytotoxicity of silver nanoparticles in human lung cells: The role of cellular uptake, agglomeration and Ag release. Part. Fibre Toxicol. 2014, 11, 11. [CrossRef] [PubMed]

253. Galbiati, V.; Cornaghi, L.; Gianazza, E.; Potenza, M.; Donetti, E.; Marinovich, M.; Corsini, E. In vitro assessment of silver nanoparticles immunotoxicity. Food Chem. Toxicol. 2018, 112, 363-375. [CrossRef] [PubMed]

254. Salama, A. Dicarboxylic cellulose decorated with silver nanoparticles as sustainable antibacterial nanocomposite material. Environ. Nanotechnol. Monit. Manag. 2017, 8, 228-232. [CrossRef]

255. Ivask, A.; ElBadawy, A.; Kaweeteerawat, C.; Boren, D.; Fischer, H.; Ji, Z.; Chang, C.H.; Liu, R.; Tolaymat, T.; Telesca, D.; et al. Toxicity mechanisms in Escherichia coli vary for silver nanoparticles and differ from ionic silver. ACS Nano 2014, 8, 374-386. [CrossRef] [PubMed]

256. Zhang, T.; Wang, L.; Chen, Q.; Chen, C. Cytotoxic potential of silver nanoparticles. Yonsei Med. J. 2014, 55, $283-291$. [CrossRef] [PubMed]

257. Ivask, A.; Kurvet, I.; Kasemets, K.; Blinova, I.; Aruoja, V.; Suppi, S.; Vija, H.; Käkinen, A.; Titma, T.; Heinlaan, M.; et al. Size-dependent toxicity of silver nanoparticles to bacteria, yeast, algae, crustaceans and mammalian cells in vitro. PLoS ONE 2014, 9, e102108. [CrossRef] [PubMed]

258. Durán, N.; Silveira, C.P.; Durán, M.; Martinez, D.S.T. Silver nanoparticle protein corona and toxicity: A mini-review. J. Nanobiotechnol. 2015, 13, 55. [CrossRef] [PubMed]

259. Nguyen, K.C.; Seligy, V.L.; Massarsky, A.; Moon, T.W.; Rippstein, P.; Tan, J.; Tayabali, A.F. Comparison of toxicity of uncoated and coated silver nanoparticles. J. Phys. Conf. Ser. 2013, 429, 012025. [CrossRef] 